Supporting Information for

\title{
Rigid Conjugated Diamine Templates for Stable Dion-Jacobson Type Two-Dimensional Perovskites
}

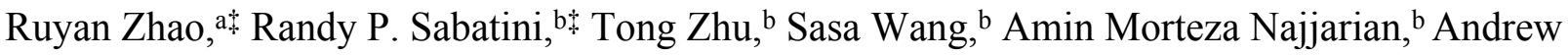
Johnston, ${ }^{\mathrm{b}}$ Alan J. Lough, ${ }^{\mathrm{a}}$ Sjoerd Hoogland, ${ }^{\mathrm{b}}$ Edward H. Sargent ${ }^{\mathrm{b}}$ and Dwight S. Seferos ${ }^{\mathrm{a}, \mathrm{c}}$

${ }^{a}$ Department of Chemistry, University of Toronto

80 St. George Street, Toronto, Ontario M5S 3H6, Canada

${ }^{b}$ Department of Electrical and Computer Engineering, University of Toronto,

10 King's College Road, Toronto, Ontario M5S 3G4, Canada

${ }^{c}$ Department of Chemical Engineering and Applied Chemistry, University of Toronto

200 College Street, Toronto, Ontario M5S 3E5, Canada

These authors contribute equally

E-mail: ted.sargent@utoronto.ca

dwight.seferos@utoronto.ca

\section{Table of Contents}

1. Experimental section

2. Synthesis of organic ligands

3. Phase impurity and single crystal structure

4. Thin film morphology

5. UV-vis absorption spectra and the Tauc plots

6. Stability measurements

7. Powder XRD patterns of (FPP) $\mathbf{P b I}_{4}$

8. DFT simulations

9. References 


\section{Summary of Figures}

Figure S1. Single crystal structure of $(\mathbf{P P}) \mathrm{Pb}_{2} \mathbf{I}_{\mathbf{6}}$

Figure S2. XRD patterns of (PP) $\mathrm{PbI}_{4},(\mathrm{PP}) \mathrm{Pb}_{2} \mathrm{I}_{6}, \mathrm{PP}-2 \mathrm{I}$, and $\mathrm{PbI}_{2}$

Figure S3. SEM images

Figure S4. UV-vis spectra and the Tauc-plots

Figure S5. The relative humidity during the measurement

Figure S6. Temperature-dependent XRD patterns

Figure S7. XRD patterns of before and after thermal treatment

Figure S8: Powder XRD patterns of (FPP)PbI $\mathbf{I}_{4}$

Figure S9. Band structure of $(\mathrm{PMA})_{2} \mathrm{PbI}_{4}$

Figure S10. Fully relaxed crystal Structure of (FPP)PbI $\mathbf{I}_{4}$ and (PMA) ${ }_{2} \mathrm{PbI}_{4}$

Figure S11. The mean square displacements as a function of temperature for (FPP)PbI $\mathbf{I}_{4}$ and $(\mathrm{PMA})_{2} \mathrm{PbI}_{4}$

Figure S12. The phonon density of states for (FPP) $\mathrm{PbI}_{4}$ and $\left(\mathrm{PMA}_{2} \mathrm{PbI}_{4}\right.$.

Figure S13. Fully relaxed structure of (FPP) $I_{2}, \mathrm{PbI}_{2},(\mathrm{PMA}) \mathrm{I},(\mathbf{F P P}) \mathbf{P b I} \mathbf{I}_{4}$, and $(\mathrm{PMA})_{2} \mathrm{PbI}_{4}$

Figure S14. Fully relaxed structure of $(\mathrm{FPP})^{2+}$, $(\mathrm{PMA})^{1+}$, cages $\left(\mathrm{PbI}_{4}\right)^{2-}$ of $(\mathbf{F P P}) \mathbf{P b I}_{4}$ and (PMA) ${ }_{2} \mathrm{PbI}_{4},(\mathbf{F P P}) \mathrm{PbI}_{4}$, and (PMA) ${ }_{2} \mathrm{PbI}_{4}$

Figure S15. ${ }^{1} \mathrm{H}$ NMR spectrum of PP2CN

Figure S16. ${ }^{13} \mathrm{C}$ NMR spectrum of PP2CN

Figure S17. ${ }^{1} \mathrm{H}$ NMR spectrum of PP-2I

Figure S18. ${ }^{13} \mathrm{C}$ NMR spectrum of PP-2I

Figure S19. ${ }^{1} \mathrm{H}$ NMR spectrum of FPP2CN

Figure S20. ${ }^{13} \mathrm{C}$ NMR spectrum of FPP2CN

Figure S21. ${ }^{1} \mathrm{H}$ NMR spectrum of FPP-2I

Figure S22. ${ }^{13} \mathrm{C}$ NMR spectrum of FPP-2I

Figure S23. ${ }^{1} \mathrm{H}$ NMR spectrum of FPT2CN

Figure S24. ${ }^{13} \mathrm{C}$ NMR spectrum of FPT2CN

Figure S25. ${ }^{1} \mathrm{H}$ NMR spectrum of FPT-2I

Figure S26. ${ }^{13} \mathrm{C}$ NMR spectrum of FPT-2I

Table S1. Crystal data and structure refinement for (FPP)PbI $\mathbf{P I}_{4}$

Table S2. Crystal data and structure refinement for FPP-2I

Table S3. Crystal data and structure refinement for $(\mathbf{P P}) \mathbf{P} \mathbf{b}_{\mathbf{2}} \mathbf{I}_{\mathbf{6}}$ 


\section{Experimental Section}

Starting Materials. 4-Iodobenzonitrile 1, 3-fluoro-4-iodobenzonitrile 2, (4cyanophenyl)boronic acid 3, thiophene-2-carbonitrile 4, lead iodide $\left(\mathrm{PbI}_{2}\right)$, hydroiodic acid (HI) (57 wt \% in water), hypophosphorous acid solution $\left(\mathrm{H}_{3} \mathrm{PO}_{2}\right)(50 \mathrm{wt} \%$ in water) were purchased from Sigma-Aldrich and used without any further purification.

Thin-film fabrication. $\mathrm{PbI}_{2}$ and the three corresponding protonated organic ligands were dissolved in DMF solution with a stoichiometric ratio of $1: 1$ and concentration in the range of $0.2-0.5 \mathrm{M}$ at $70{ }^{\circ} \mathrm{C}$. The solution was then allowed to cool to room temperature. All thin films were spin coated from their respective DMF solutions at $3000 \mathrm{rpm}$ for $40 \mathrm{~s}$, followed by thermal annealing. (FPP) $\mathbf{P b I}_{4}$ and (FPT) $\mathbf{P b I}_{4}$ films form the desired perovskite phase after thermal annealing at $80{ }^{\circ} \mathrm{C}$ for several minutes. However, (PP) $\mathbf{P b I}_{4}$ thin films require thermal annealing at $120^{\circ} \mathrm{C}$.

Scanning electron microscopy (SEM). Thin film SEM images were acquired using a QUANTA FEG 250 SEM.

Single crystal growth. Single crystals were grown using both slow-cooling method and antisolvent method. A typical procedure of slow-cooling method: $\mathrm{PbI}_{2}$ and organic ligand are fully dissolved in hot $\left(200{ }^{\circ} \mathrm{C}\right) \mathrm{HI} / \mathrm{H}_{3} \mathrm{PO}_{2}(v: v=5: 1)$ solution while stirring, and then put the clear solution into preheated oven and then slow-cooled to room temperature within 45 hours. We also tried anti-solvent method, but it leads to solvent-incorporated lower dimensional perovskites.

Single crystal structure. Single-crystal structures were measured with Bruker Kappa APEXDUO diffractometer equipped with a rotating anode with graphite-monochromated Mo-K $\alpha$ radiation (Burker Triumph, $\lambda=0.71073 \AA$ ). The structures were solved by SHLEXT and SHELXL-2016/6, respectively.

Linear absorption spectroscopy. Linear absorption spectra were collected using a PerkinElmerLAMBDA $950 \mathrm{UV} /$ vis/NIR spectrophotometer with an integrating sphere.

Steady-state photoluminescence. Photoluminescence spectra were collected on a Horiba Fluorolog TCSPC system with an iHR 320 monochromator and a PPD 900 detector. 
Thin film XRD patterns. Thin-film XRD patterns were collected on a Rigaku MiniFlex 600 6G Benchtop powder X-ray diffraction (XRD) instrument using $\mathrm{Cu} \mathrm{K} \alpha$ radiation $(\lambda=1.5406$ $\AA$ ). For temperature dependent measurements, samples were heated using the TS 500 high temperature attachment and data were collected at intervals of $10 \mathrm{oC}$.

DFT calculation details. The DFT calculations were performed using the FHI-aims allelectron code. ${ }^{1-3}$ The default numerical settings, referred to as "intermediate" in FHI-aims were used. Local minimum-energy geometries of the Born-Oppenheimer surface were obtained with residual total energy gradients below $1 \times 10^{-2} \mathrm{eV} \AA^{-1}$ for atomic positions by PBE-GGA functional ${ }^{4}$ within the $v d W$ correction following the Tkatcheko-Scheffler method ${ }^{5}$ (PBE+TS). The band structures and densities of states (DOS) are calculated following the short-range screened hybrid exchange-correlation functional $\mathrm{HSE}^{6} 6^{6}$, with fixed screening parameters $\omega$ $=0.2 \AA^{-1}$ and exchange mixing parameter $\alpha=0.25$, including spin-orbit coupling ${ }^{7}$ with a $k$ point grid of $5 \times 5 \times 5$ to sample the Brillouin zone that corresponds to the unit cell shown in Figures S4. The phonon band structure and mean-square displacements are calculated using the finite displacement method, as implemented in the Phonopy code ${ }^{8}$. The $1 \times 2 \times 2(2 \times 2 \times 2)$ supercells for $(\mathrm{FPP}) \mathrm{PbI}_{4}\left((\mathrm{PMA})_{2} \mathrm{PbI}_{4}\right)$ and a reduced k-point sampling $2 \times 1 \times 1$ are used for force calculations, with a force convergence parameter $10^{-6} \mathrm{eV} \AA^{-1}$, following the PBE + TS approach. The $30 \times 30 \times 30$ mesh for the $q$ points was used in the calculation of the phonon band structures. 


\section{Synthesis of Organic Ligands}

Synthesis of 2-fluoro-[1,1'-biphenyl]-4,4'-dicarbonitrile PP2CN. 4-Iodobenzonitrile 1 (1000 mg, $4.370 \mathrm{mmol}$ ), (4-cyanophenyl)boronic acid 3 (1283 mg, $8.730 \mathrm{mmol}$ ), $\mathrm{K}_{2} \mathrm{CO}_{3}$ (2 M in water, $4.580 \mathrm{~mL}, 9.170 \mathrm{mmol})$, and XPhous Pd G2 (68.71 mg, $0.09 \mathrm{mmol}$ ) was added to a vial containing $15 \mathrm{~mL}$ THF. The mixture was degassed for 30 minutes and stirred at $65{ }^{\circ} \mathrm{C}$ for 1.5 hours in microwave rector. The solution was cooled to room temperature and poured into water. The solution was extracted with dichloromethane and the combined organic phase was washed with brine, dried over anhydrous magnesium sulfate, and then filtered. The solvent was removed under reduced pressure. The crude product was purified with column chromatography (hexane: $\mathrm{CH}_{2} \mathrm{Cl}_{2}$ from 1:1 to 1:3) and collected as a white solid (892 mg, 95\%). ${ }^{1} \mathrm{H} \mathrm{NMR}\left(\mathrm{CDCl}_{3}, 500 \mathrm{MHz}\right) \delta 7.81-7.76(\mathrm{~m}, 4 \mathrm{H}), 7.72-7.68(\mathrm{~m}, 4 \mathrm{H}) .{ }^{13} \mathrm{C} \mathrm{NMR}\left(\mathrm{CDCl}_{3}, 126\right.$ MHz) $\delta 143.52,132.89,127.94,118.41,112.43$. DART calcd for $\mathrm{C} 14 \mathrm{H} 12 \mathrm{~N} 3\left[\mathrm{M}+\mathrm{NH}_{4}\right]^{+}$ 222.10, found: 222.10 .

Synthesis of PP-2I. $\mathrm{Ph}_{2} \mathrm{SiH}_{2}(1.99 \mathrm{~mL}, 10.77 \mathrm{mmol})$ was added to the solution of $\mathrm{B}\left(\mathrm{C}_{6} \mathrm{~F}_{5}\right)_{3}$ (66.18 $\mathrm{mg}, 0.130 \mathrm{mmol}$ ) and PP2CN (220.0 mg, $1.080 \mathrm{mmol}$ ) in dry $\mathrm{CH}_{2} \mathrm{Cl}_{2}$ under argon atmosphere. The solution was stirred for 1.5 hours at room temperature. Volatiles were removed in vacuo and $1 \mathrm{M} \mathrm{HI}$ solution $(5 \mathrm{~mL})$ was added, stirred it for $1 \mathrm{~h}$ at room temperature. PP-2I was washed with ether by vigorously stirring and collected by filtration as a white solid (490 mg, 97\%). ${ }^{1} \mathrm{H}$ NMR (DMSO, $400 \mathrm{MHz}$ ), $\delta 8.14$ (s, 1H), 7.97-7.69 (m, 1H), 7.69-7.42 (m, 1H), 4.11 (s, 1H). ${ }^{13} \mathrm{C}$ NMR (DMSO, $126 \mathrm{MHz}$ ), $\delta$ 139.99, 133.84, 130.02, 127.32, 42.43.

\section{Synthesis of 2-fluoro-[1,1'-biphenyl]-4,4'-dicarbonitrile FPP2CN. 3-Fluoro-4-} iodobenzonitrile 2 (1000 mg, $4.05 \mathrm{mmol}$ ), (4-cyanophenyl)boronic acid 3 (1189 mg, 8.100 $\mathrm{mmol}), \mathrm{K}_{2} \mathrm{CO}_{3}(2 \mathrm{M}$ in water, $4.250 \mathrm{~mL}, 8.500 \mathrm{mmol}$ ), and XPhous Pd G2 (63.71 mg, 0.08 mmol) was added to a vial containing $15 \mathrm{~mL}$ THF. The mixture was degassed for 30 minutes and stirred at $65{ }^{\circ} \mathrm{C}$ for 1.5 hours in microwave rector. The solution was cooled to room temperature and poured into water. The solution was extracted with $\mathrm{CH}_{2} \mathrm{Cl}_{2}$ and the combined organic phase was washed with brine, dried over $\mathrm{MgSO}_{4}$, and then filtered. The solvent was removed under reduced pressure. The crude product was purified with column chromatography (hexane: $\mathrm{CH}_{2} \mathrm{Cl}_{2}$ from 1:1 to $1: 3$ ) and collected as a white solid (852 mg, 95\%). ${ }^{1} \mathrm{H}$ NMR $\left(\mathrm{CDCl}_{3}, 500 \mathrm{MHz}\right), \delta$ 7.82-7.74 (m, 2H), 7.69-7.63 (m, 2H), 7.60-7.53 (m, 2H), 7.53-7.48 (m, 1H). ${ }^{13} \mathrm{C}$ NMR $\left(\mathrm{CDCl}_{3}, 101 \mathrm{MHz}\right), \delta 160.12,157.86,138.28,132.55,131.55-131.51$, 
129.71-129.68, 128.68-128.63, 120.42, 120.16, 118.27, 117.16, 113.93, 113.83, 112.90. DART calcd for C14H11FN3 [M+NH$]^{+} 240.09$, found: 240.10 .

Synthesis of FPP-2I. $\mathrm{Ph}_{2} \mathrm{SiH}_{2}(1.850 \mathrm{~mL}, 9.990 \mathrm{mmol})$ was added to the solution of $\mathrm{B}\left(\mathrm{C}_{6} \mathrm{~F}_{5}\right)_{3}$ (61.38 mg, $0.120 \mathrm{mmol})$ and FPP2CN $(222.0 \mathrm{mg}, 1.000 \mathrm{mmol})$ in dry $\mathrm{CH}_{2} \mathrm{Cl}_{2}$ under argon atmosphere. The solution was stirred for 1.5 hours at room temperature. The volatiles were removed in vacuo and $1 \mathrm{M} \mathrm{HI}$ solution $(5 \mathrm{~mL})$ was added and stirred for $1 \mathrm{~h}$ at room temperature. FPP-2I was washed with ether by vigorously stirring and collected by filtration as a white solid (480 mg, 98\%). ${ }^{1} \mathrm{H}$ NMR (DMSO, $\left.500 \mathrm{MHz}\right) \delta 8.14$ (s, 6H), 7.61 (ddd, $J=$ 8.2, 4.8, 3.2 Hz, 3H), 7.57-7.53 (m, 2H), 7.44 (dd, $J=11.7,1.7 \mathrm{~Hz}, 1 \mathrm{H}), 7.38$ (dd, $J=8.0,1.7$ $\mathrm{Hz}, 1 \mathrm{H}), 4.10$ (d, $J=6.9 \mathrm{~Hz}, 4 \mathrm{H}) .{ }^{13} \mathrm{C}$ NMR (DMSO, $\left.126 \mathrm{MHz}\right) \delta 160.18,158.21,136.53-$ $136.46,135.11,134.33,131.44-131.41,129.69,129.47-129.45,128.17-128.06,125.92-$ $125.89,117.15,116.97,42.45,41.97-41.96$.

Synthesis of 5-(trimethylstannyl)thiophene-2-carbonitrile 5. 2-Cyanothiophene 4 (2.180 g, $20.00 \mathrm{mmol}$ ) was added to $40 \mathrm{~mL}$ dry, and degassed THF and the solution was cooled to -78 ${ }^{\circ} \mathrm{C}$. LDA (2.0 M in THF, $10.00 \mathrm{~mL}, 20.00 \mathrm{mmol}$ ) was added dropwise. The solution was stirred at $-78{ }^{\circ} \mathrm{C}$ for 1 hour and trimethyltin chloride $(1.0 \mathrm{M}$ in THF, $20.00 \mathrm{~mL}, 20.00 \mathrm{mmol})$ was added via syringe slowly. The mixture was stirred at $-78^{\circ} \mathrm{C}$ for 30 minutes and then at ambient temperature overnight. The mixture was extracted with ether and water. The ether phase was combined and washed with brine and dried over $\mathrm{MgSO}_{4}$. After removal of solvent, the crude product was collected by distillation. ${ }^{1} \mathrm{H} \mathrm{NMR}\left(\mathrm{CDCl}_{3}, 400 \mathrm{MHz}\right), \delta 7.70(\mathrm{~d}, J=3.5 \mathrm{~Hz}, 1 \mathrm{H})$, $7.16(\mathrm{~d}, J=3.5 \mathrm{~Hz}, 1 \mathrm{H}), 0.43(\mathrm{~s}, 9 \mathrm{H})$.

Synthesis of 5-(4-cyano-2-fluorophenyl)thiophene-2-carbonitrile FPT2CN. 3-Fluoro-4iodobenzonitrile 2 (931.0 mg, $3.769 \mathrm{mmol})$, 5-(trimethylstannyl)thiophene-2-carbonitrile 5 (1230 mg, $4.523 \mathrm{mmol})$, and $\mathrm{Pd}\left(\mathrm{PPh}_{3}\right)_{4}(435.5 \mathrm{mg}, 0.377 \mathrm{mmol})$ was added to a vial containing $15 \mathrm{~mL}$ toluene. The mixture was degassed for 30 minutes and stirred at $110^{\circ} \mathrm{C}$ for 3 hours in microwave rector. The solution was cooled to room temperature and poured into water. The solution was extracted with $\mathrm{CH}_{2} \mathrm{Cl}_{2}$ and the combined organic phase was washed with brine, dried over $\mathrm{MgSO}_{4}$, and then filtered. The solvent was removed under reduced pressure. The crude product was purified with column chromatography (hexane: $\mathrm{CH}_{2} \mathrm{Cl}_{2}$ from 1:1 to 1:3) and recrystallized from the mixture of hexane and dichloromethane as a white solid (615 $\mathrm{mg}, 71 \%)$. 
${ }^{1} \mathrm{H}$ NMR $\left(\mathrm{CD}_{2} \mathrm{Cl}_{2}, 400 \mathrm{MHz}\right) \delta 7.83(\mathrm{dd}, J=8.4,7.4 \mathrm{~Hz}, 1 \mathrm{H}), 7.74(\mathrm{dd}, J=4.1,1.2 \mathrm{~Hz}, 1 \mathrm{H})$, $7.62(\mathrm{dd}, J=4.1,1.0 \mathrm{~Hz}, 1 \mathrm{H}), 7.61-7.55(\mathrm{~m}, 2 \mathrm{H}) .{ }^{13} \mathrm{C} \mathrm{NMR}\left(\mathrm{CD}_{2} \mathrm{Cl}_{2}, 126 \mathrm{MHz}\right) \delta 159.43$, $157.41,141.61,137.95,129.56,128.78,127.86,125.05,120.50,117.00,113.64,111.46$. DART calcd for C12H9FN3S [M+NH$]^{+} 246.05$, found: 246.05 .

Synthesis of FPT-2I. $\mathrm{Ph}_{2} \mathrm{SiH}_{2}(1.210 \mathrm{~mL}, 6.570 \mathrm{mmol})$ was added to the solution of $\mathrm{B}\left(\mathrm{C}_{6} \mathrm{~F}_{5}\right)_{3}$ (40.38 mg, $0.079 \mathrm{mmol}$ ) and FPT2CN (150.0 mg, $0.657 \mathrm{mmol})$ in dry $\mathrm{CH}_{2} \mathrm{Cl}_{2}$ under argon atmosphere. The solution was stirred for 1.5 hours at room temperature. The volatiles were removed in vacuo and $1 \mathrm{M} \mathrm{HI}$ solution $(3 \mathrm{~mL})$ was added and stirred for $1 \mathrm{~h}$ at room temperature. FPT-2I was washed with ether by vigorously stirring and collected by filtration as a white solid (308 mg, 95\%). ${ }^{1} \mathrm{H}$ NMR (DMSO, $\left.500 \mathrm{MHz}\right), \delta 8.20$ (s, 7H), 7.88 (t, $J=8.2$ $\mathrm{Hz}, 1 \mathrm{H}), 7.59$ (d, $J=3.7 \mathrm{~Hz}, 1 \mathrm{H}), 7.48(\mathrm{dd}, J=12.4,1.7 \mathrm{~Hz}, 1 \mathrm{H}), 7.38$ (dd, $J=8.1,1.7 \mathrm{~Hz}$, 1H), $7.30(\mathrm{dd}, J=3.8,1.3 \mathrm{~Hz}, 1 \mathrm{H}), 4.32$ (s, 2H), 4.11 (s, 2H). ${ }^{13} \mathrm{C}$ NMR (DMSO, $126 \mathrm{MHz}$ ), $\delta 159.10,157.12$, 137.00-136.95, 136.67-136.63, 136.21-136.15, 130.25, 129.03-129.00, 127.21-127.18, 126.18-126.16, 121.42-121.32, 117.43-117.25, 41.86, 37.38. 


\section{Phase Impurity and Single Crystal Structure}

Note 1:

To investigate the phase impurity in (PP) $\mathbf{P b I}_{4}$, we first excluded the possibilities of remaining organic ligand of (PP-2I) and $\mathrm{PbI}_{2}$ by comparing their XRD patterns. Then we looked further into its single crystal growth. Single crystals of PP ligand incorporated perovskite were grown via the slow-cooling method. Single crystal XRD revealed these crystals to be 1D perovskites with the empirical chemical formula of (PP) $\mathrm{Pb}_{2} \mathrm{I}_{6}$ (Figure S1, Table S3). When we simulate the XRD pattern of this 1D single crystal, we find that the major peak is at the same degree as the impurity peak in the spin-coated film (Figure S2). We therefore attribute the impurity to a lowerdimensional species.
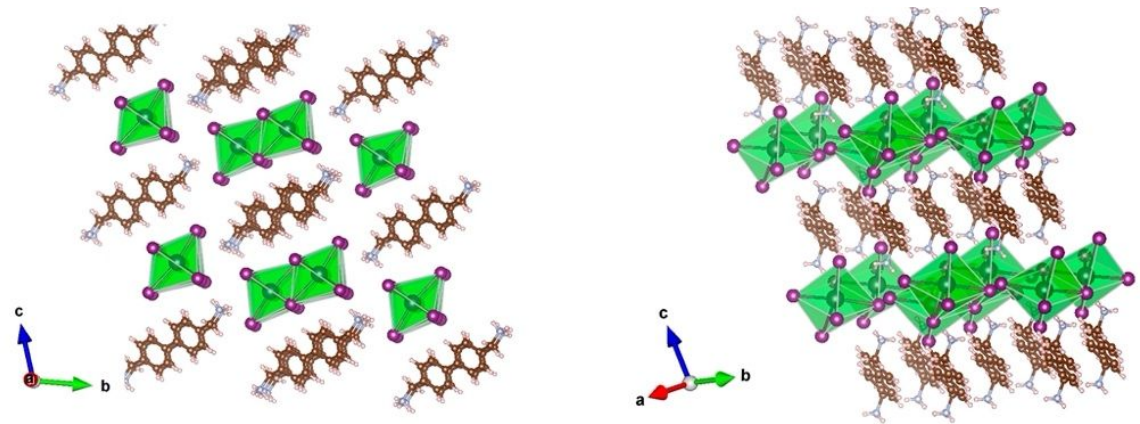

Figure S1. Single crystal structure of $(\mathbf{P P}) \mathbf{P} \mathbf{b}_{2} \mathbf{I}_{6}$.

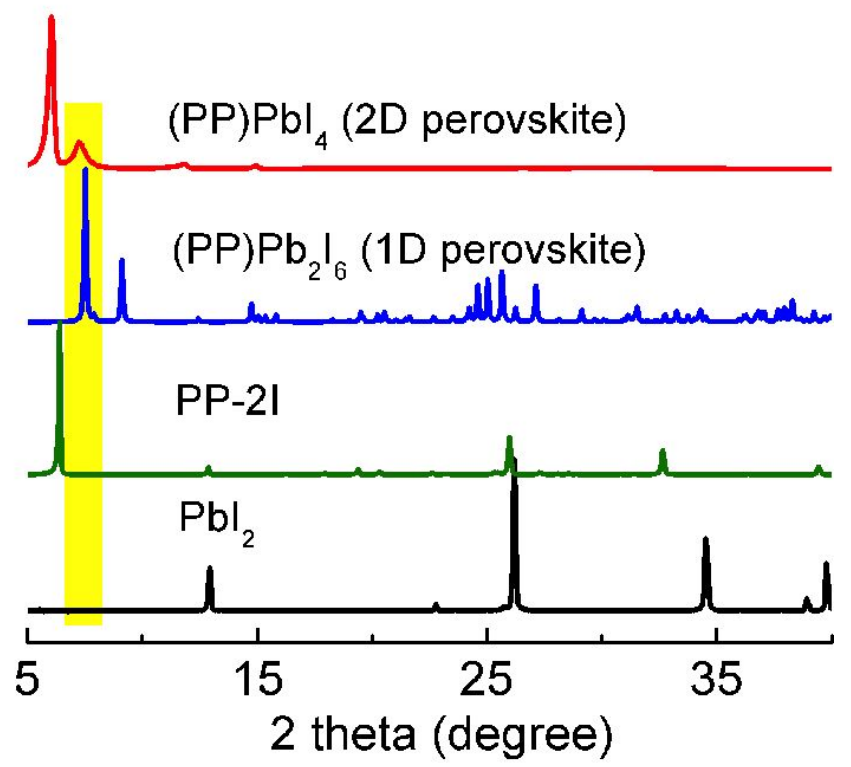

Figure S2. XRD patterns of (PP) $\mathrm{PbI}_{4},(\mathrm{PP}) \mathrm{Pb}_{2} \mathrm{I}_{6}$ (simulated), $\mathrm{PP}-2 \mathrm{I}$, and $\mathrm{PbI}_{2}$. 
Unlike (PP) $\mathbf{P b I}_{4}$, the thin films of (FPP) $\mathbf{P b I}_{4}$ and $(\mathbf{F P T}) \mathbf{P b I}_{4}$ contain no impurity phase. We believe that this is due to the introduction of the fluorine atom, which can enhance the interaction between the organic ligands.

During the temperature-dependent XRD measurements, (FPT) $\mathbf{P b I}_{4}$ undergoes an irreversible phase transition. We ascribe this tentatively to a transition to a lower-dimensional phase (like the impurity present in (PP) $\mathbf{P b I}_{4}$. 


\section{Film Morphology}
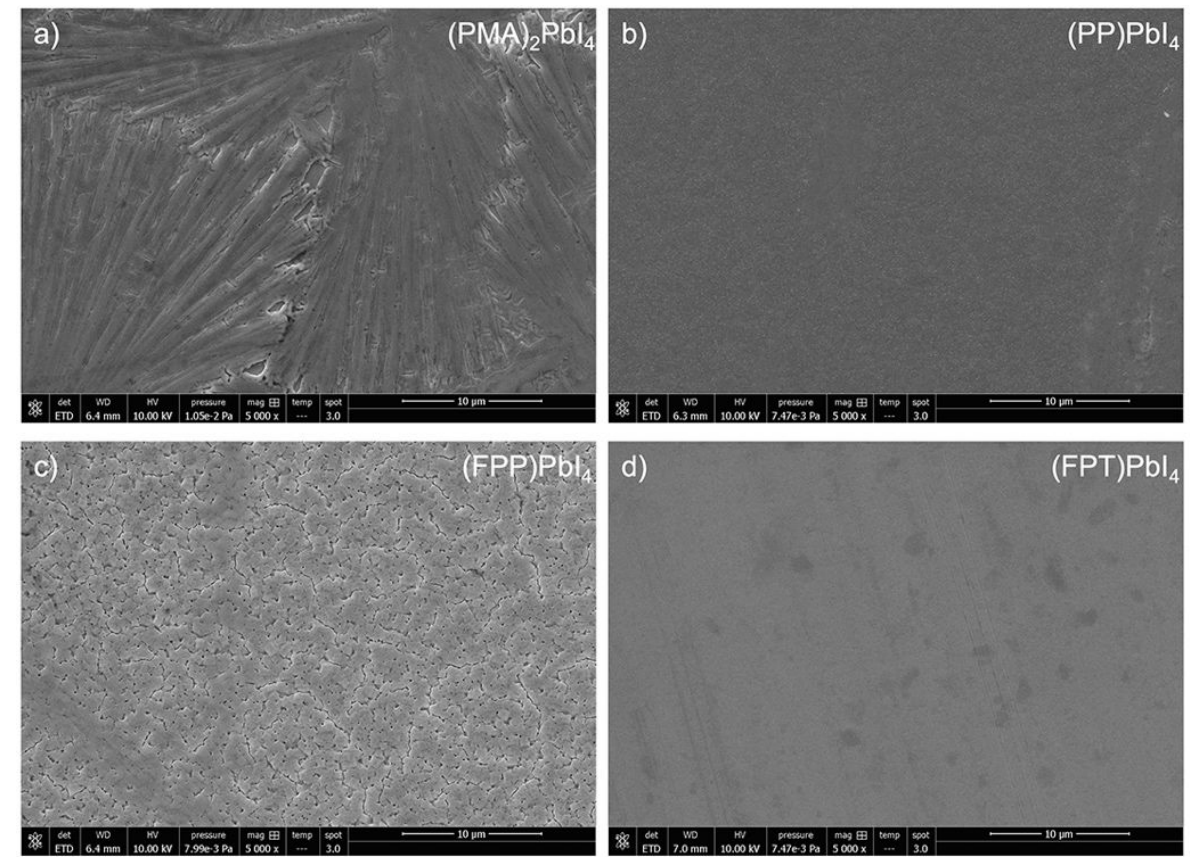

Figure S3. SEM images of the thin films of a). (PMA) ${ }_{2} \mathrm{PbI}_{4}$, b). (PP)PbI 4 , c). (FPP)PbI (FPT)PbI 4 . 


\section{UV-vis Absorption Spectra and the Tauc Plots}
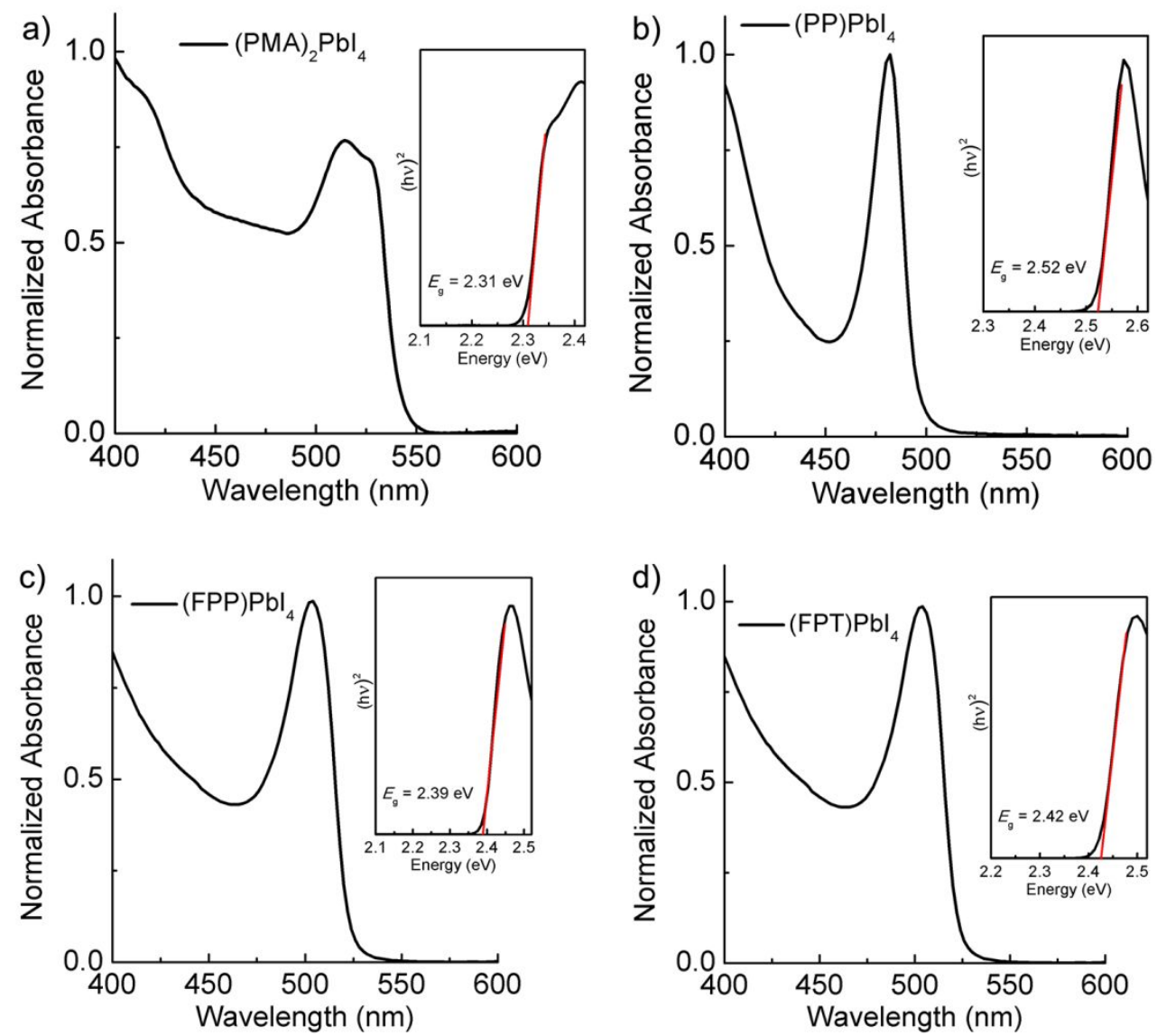

Figure S4. UV-vis spectra of the thin-films of a). ( $\left.\mathrm{PMA}_{2} \mathrm{PbI}_{4}, \mathrm{~b}\right)$. ( $\left.\left.\mathrm{PP}\right) \mathrm{PbI}_{4}, \mathrm{c}\right)$. (FPP) $\mathrm{PbI}_{4}$, and d). (FPT) $\mathrm{PbI}_{4}$. The insets are the corresponding Tauc-plots for each thin film. 


\section{Stability Measurements}
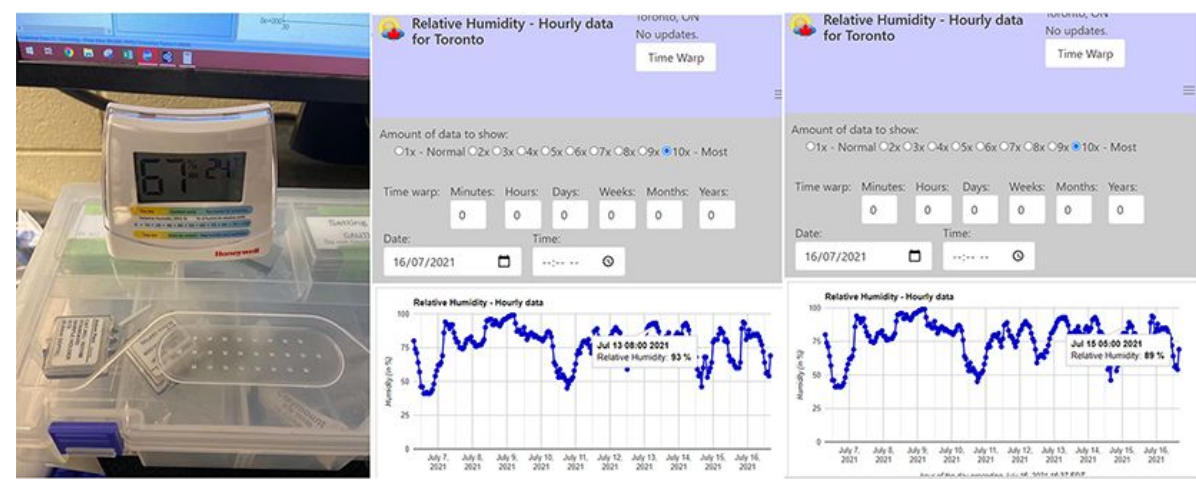

Figure S5. The relative humidity of the surrounding environment during the measurements.

a)

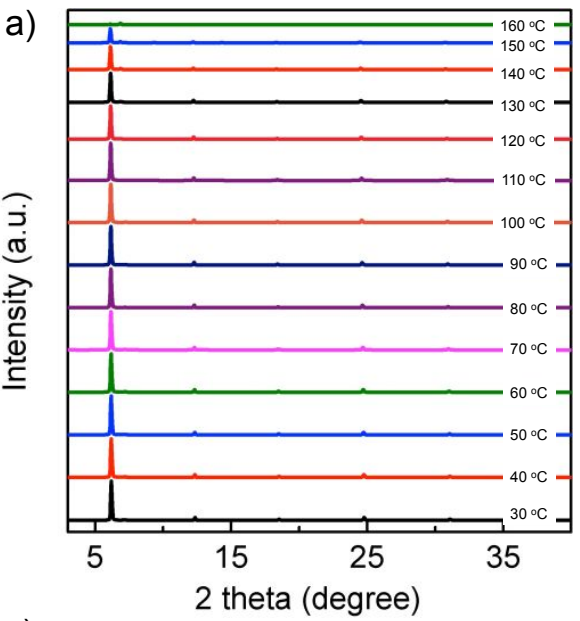

c)

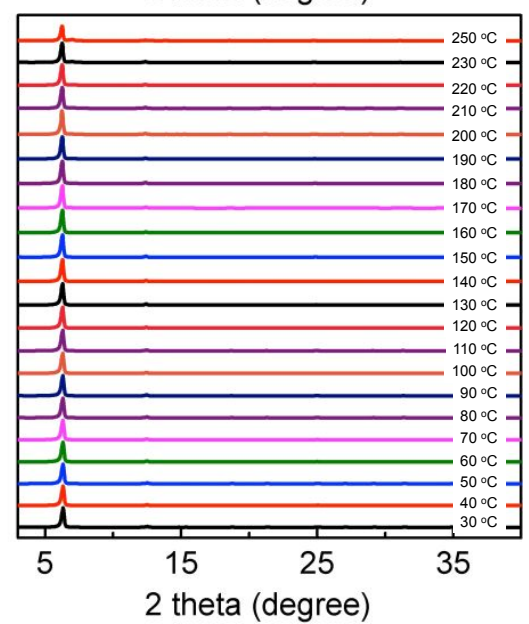

b)

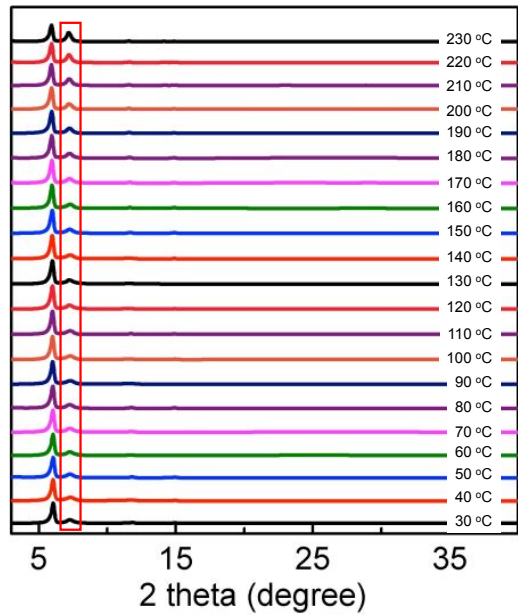

d)
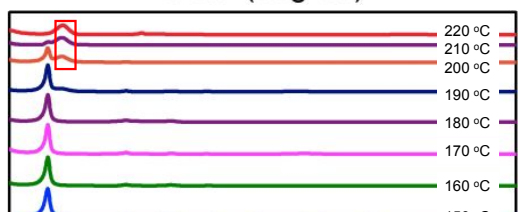

ذ.
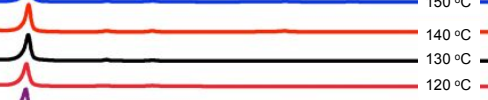

1
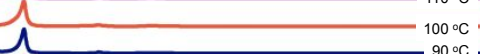

$\underbrace{\circ} 0^{\circ} \mathrm{C}$
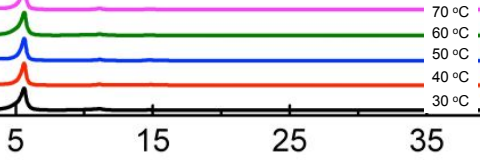

2 theta (degree)

Figure S6. Temperature-dependent XRD patterns of a) $\left(\mathrm{PMA}_{2} \mathrm{PbI}_{4}\right.$, b) $(\mathbf{P P}) \mathbf{P b I}_{4}$, c) $(\mathbf{F P P}) \mathbf{P b I}_{4}$, and d) (FPT) $\mathbf{P b I}_{4} 2 \mathrm{D}$ perovskite thin films. 

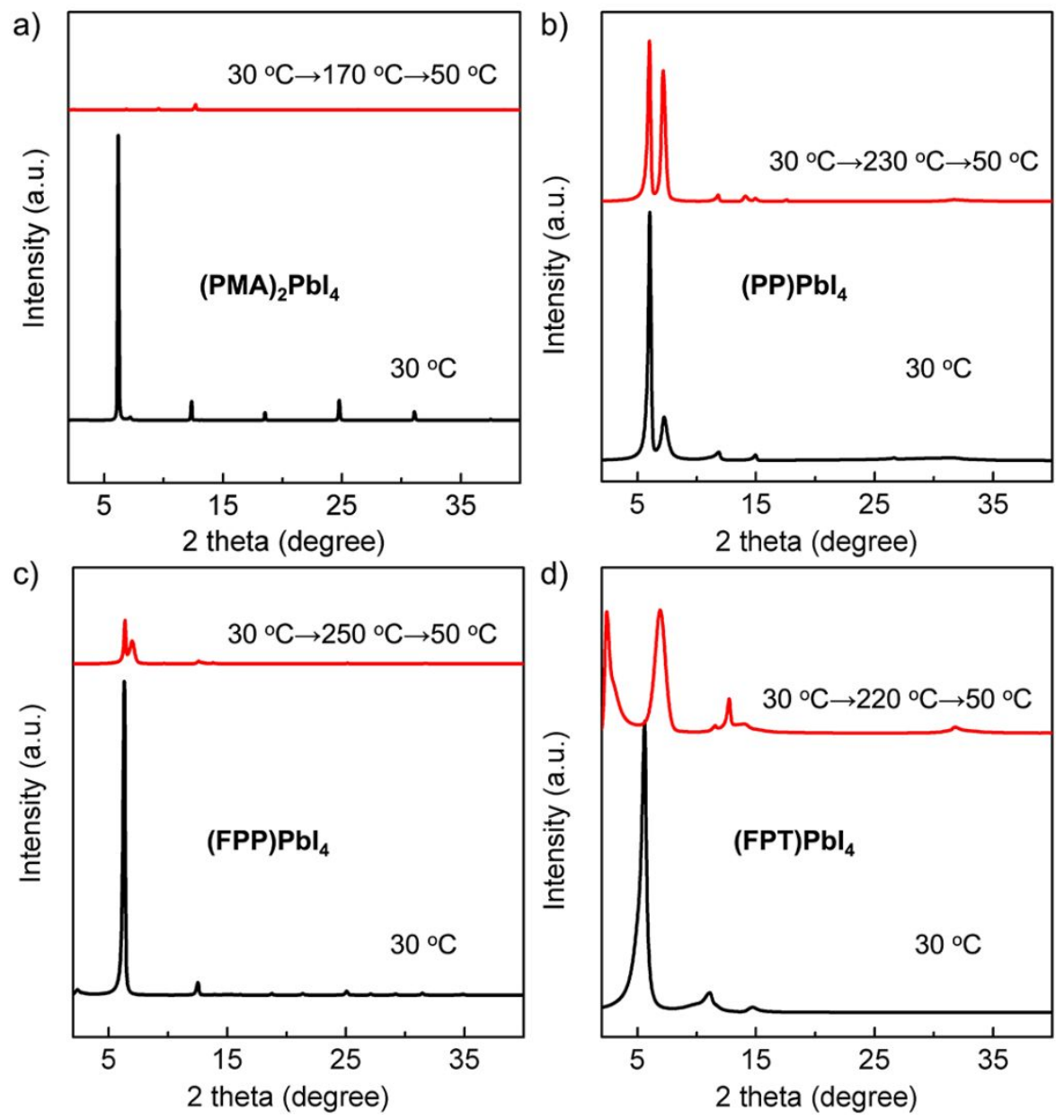

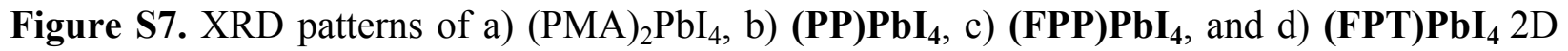
perovskite thin films at $30^{\circ} \mathrm{C}$ (black line) and cool back again to low temperature (red line). 
7. Powder XRD patterns of (FPP)PbI

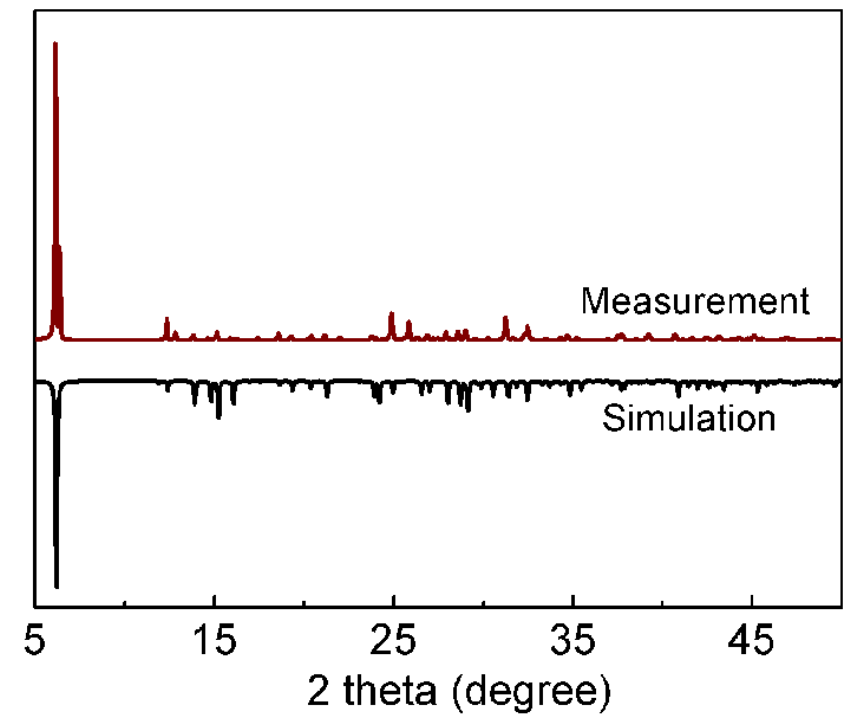

Figure S8. Simulated $\mathrm{pXRD}$ and measured XRD of the single crystal of (FPP)PbI 4 . 


\section{DFT Simulations}

a)

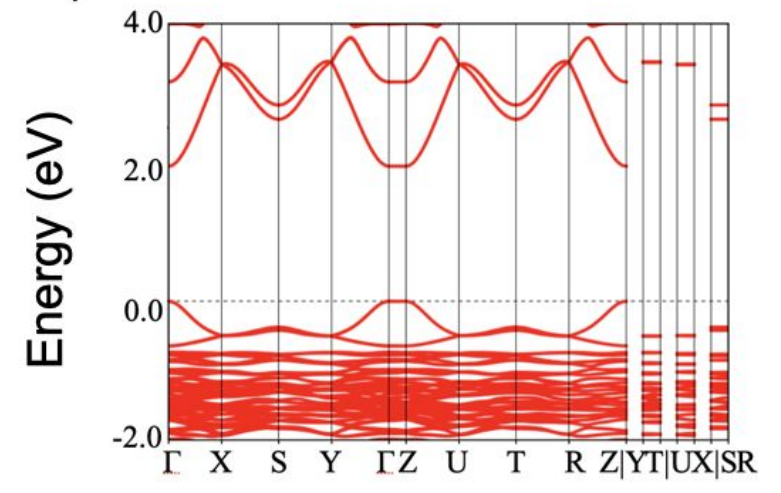

b)

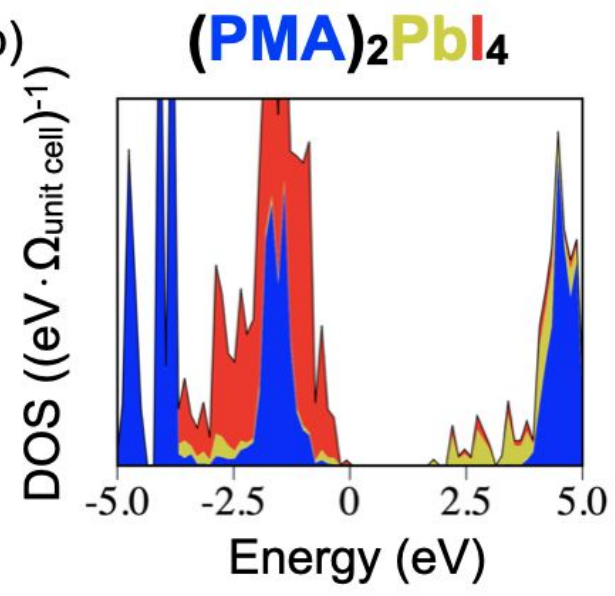

Figure S9. a) The HSE06+SOC calculated band structure and b) total density of states (DOS) and element-decomposed DOS for ( $\mathrm{PMA})_{2} \mathrm{PbI}_{4}$. The contribution of the ligands, $\mathrm{Pb}, \mathrm{I}$ in the $\mathrm{DOS}$ are shown in blue, dark yellow, and red, respectively.
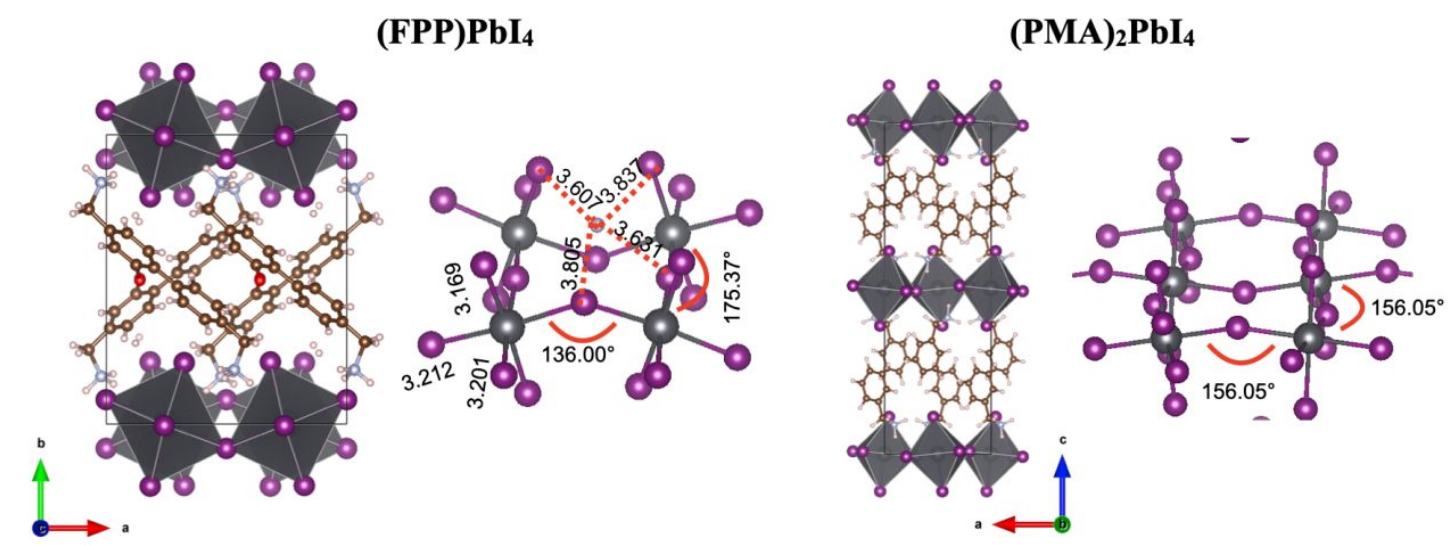

Figure S10. Crystal Structure of (FPP) $\mathrm{PbI}_{4}$ and $\left(\mathrm{PMA}_{2} \mathrm{PbI}_{4}\right.$, fully relaxed by DFT-PBE+TS taking the experimental (x-ray diffraction) structure as the input. The (FPP)PbI $\mathbf{P}_{4}$ experimental structure are obtained through this work, and the $(\mathrm{PMA})_{2} \mathrm{PbI}_{4}$ are obtained based on the reference ${ }^{9}$. The corresponding distortion ( $\mathrm{Pb}-\mathrm{I}-\mathrm{Pb}$ angle), N-I distance and $\mathrm{Pb}-\mathrm{I}$ bond length are also labeled. $\mathrm{The} \mathrm{Pb}, \mathrm{I}, \mathrm{C}, \mathrm{N}, \mathrm{H}, \mathrm{F}$ atoms are represented by grey, purple, brown, light blue, pearl, and red color, respectively. 

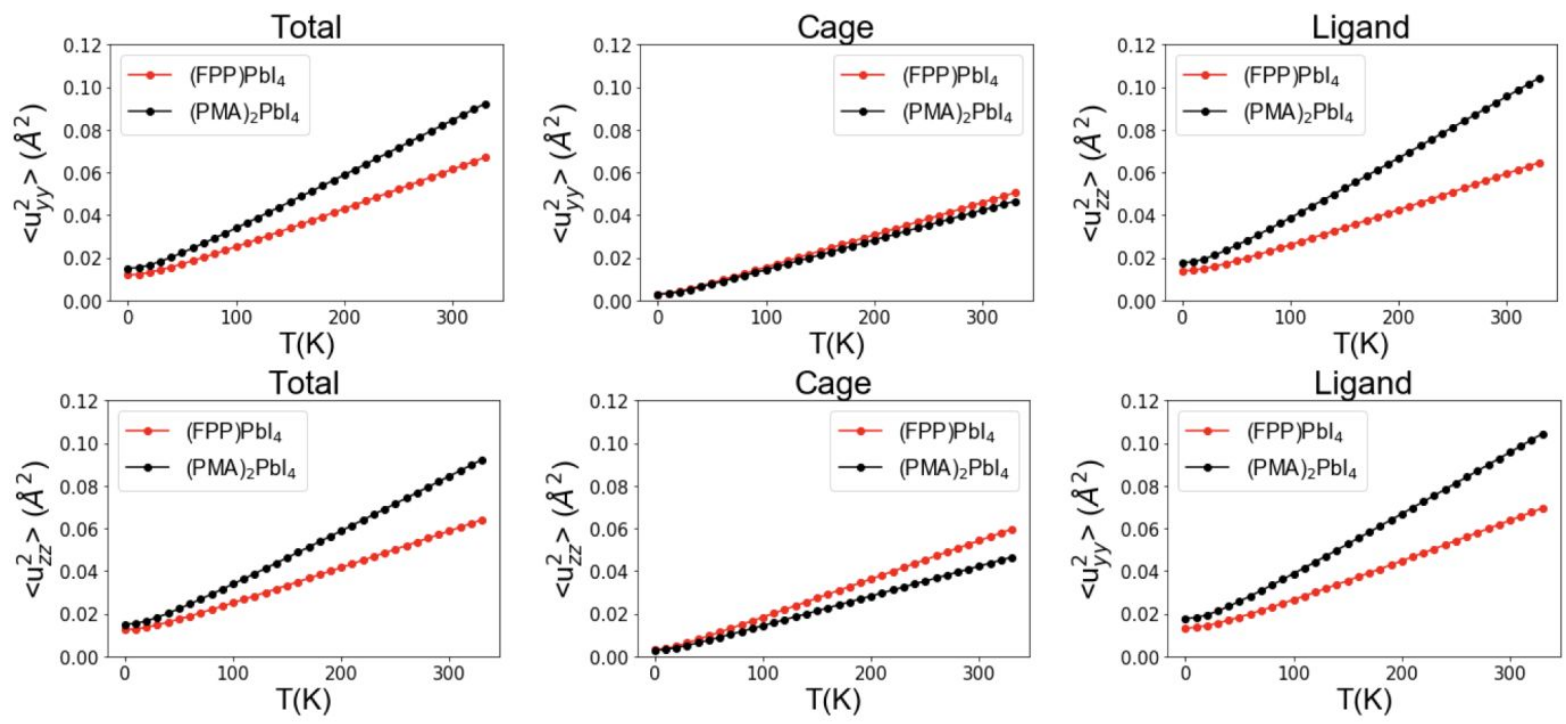

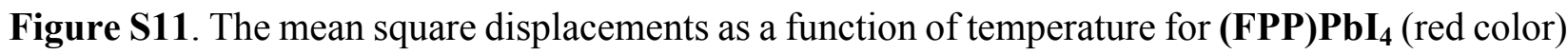
and ( $\mathrm{PMA})_{2} \mathrm{PbI}_{4}$ (black color). The contributions from the whole structure, $\mathrm{Pb}$-I cages, and organic ligands are shown separately. Slope indicates the mean force constants.
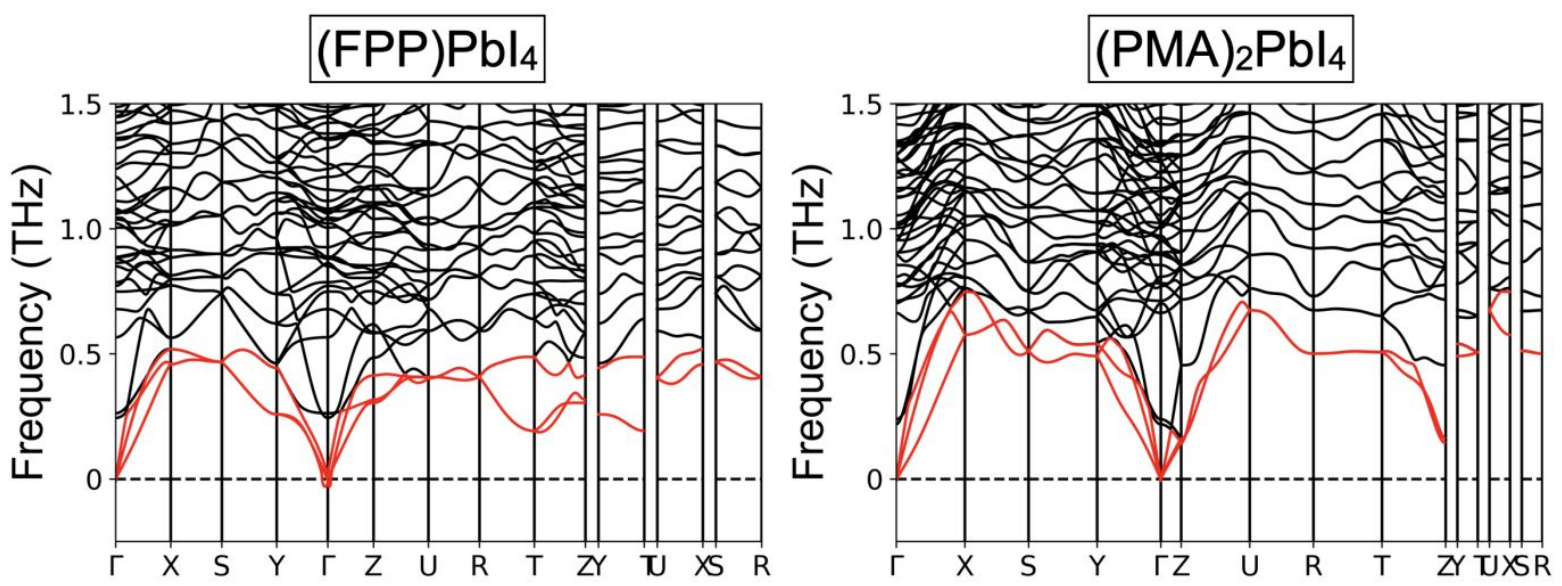

Figure S12. The phonon band structure for (FPP) $\mathbf{P b I}_{4}$ and (PMA) ${ }_{2} \mathrm{PbI}_{4}$. The acoustic phonon modes are shown in red color, and the optic phonon modes are shown in black color. 


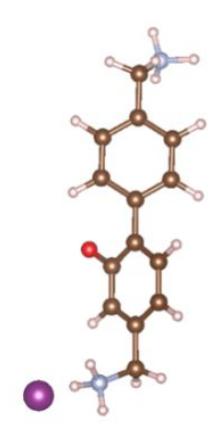

$\left.(\mathrm{FPP})\right|_{2}$

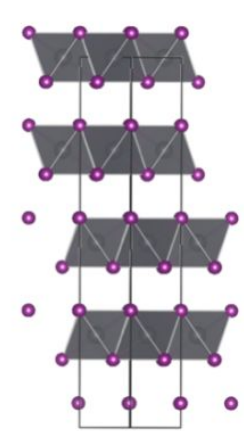

$\mathrm{Pbl}_{2}\left(P 6_{3} m c\right)$
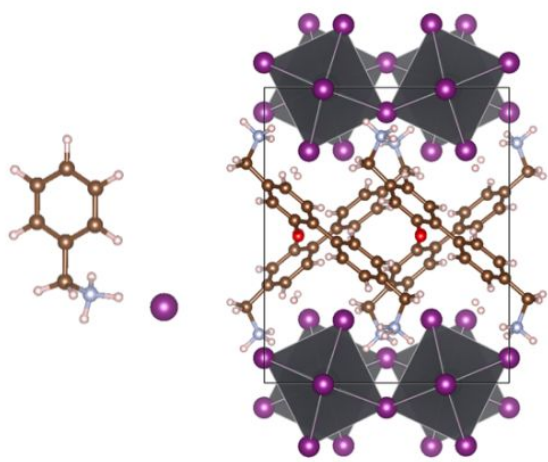

(FPP)Pbl 4

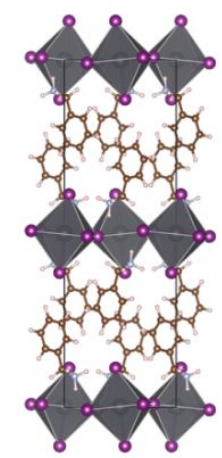

$(\mathrm{PMA})_{2} \mathrm{Pbl}_{4}$

$$
\begin{aligned}
& (\mathrm{FPP}) \mathrm{I}_{2}+\mathrm{Pbl}_{2} \rightarrow(\mathrm{FPP}) \mathrm{Pbl}_{4} \\
& 2(\mathrm{PMA}) \mathrm{l}+\mathrm{Pbl}_{2} \rightarrow(\mathrm{PMA})_{2} \mathrm{Pbl}_{4}
\end{aligned}
$$

\section{$-3.88 \mathrm{eV} /$ formula \\ $-4.19 \mathrm{eV} /$ formula}

Figure S13. The structure of (FPP) $\mathrm{I}_{2}, \mathrm{PbI}_{2}$ (in space group $P 6_{3} m c$ ), (PMA)I, (FPP) $\mathbf{P b I}_{4}$, and $(\mathrm{PMA})_{2} \mathrm{PbI}_{4}$, fully relaxed by $\mathrm{PBE}+\mathrm{TS}$. The $(\mathbf{F P P}) \mathbf{P b I}_{4}$ and $(\mathrm{PMA})_{2} \mathrm{PbI}_{4}$ are taking the experimental structure as input, more details are shown in the citation of Figure S10. The formation energies are listed for each compound.

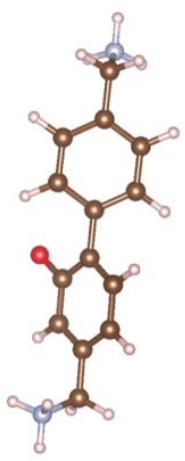

$(\mathrm{FPP})^{2+}$

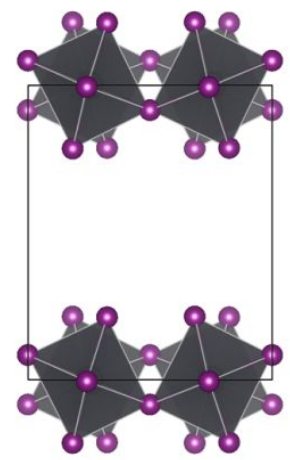

$\left(\mathrm{Pbl}_{4}\right)^{2-}$

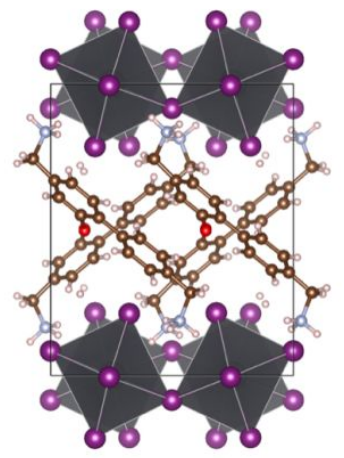

(FPP)Pbl 4
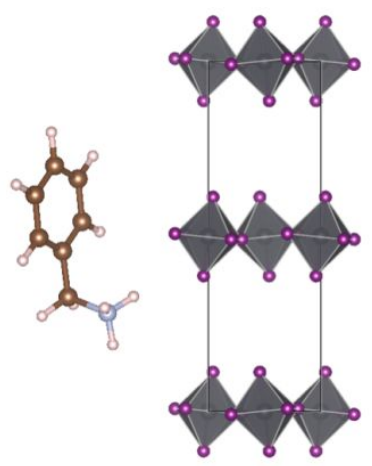

(PMA) $)^{1+}$
$\left(\mathrm{Pbl}_{4}\right)^{2-}$

$$
\begin{gathered}
2(\mathrm{PMA})^{1+}+\left(\mathrm{Pbl}_{4}\right)^{2-} \rightarrow(\mathrm{FPP}) \mathrm{Pbl} 4 \\
-7.85 \mathrm{eV} / \text { formula }
\end{gathered}
$$

Figure S14. The structure of $(\mathrm{FPP})^{2+},(\mathrm{PMA})^{1+}$, cages $\left(\mathrm{PbI}_{4}\right)^{2-}$ of $(\mathbf{F P P}) \mathrm{PbI}_{4}$ and $\left(\mathrm{PMA}_{2} \mathrm{PbI}_{4}\right.$, (FPP) $\mathrm{PbI}_{4}$, and (PMA) ${ }_{2} \mathrm{PbI}_{4}$, fully relaxed by $\mathrm{PBE}+\mathrm{TS}$. The (FPP) $\mathrm{PbI}_{4}$ and (PMA) $)_{2} \mathrm{PbI}_{4}$ are taking the experimental structure as input, more details are shown in the citation of Figure S10. For the cages $\left(\mathrm{PbI}_{4}\right)^{2-}$, the structures are directly obtained from the fully $\mathrm{PBE}+\mathrm{TS}$ relaxed (FPP) $\mathbf{P b I}_{4}$ and $(\mathrm{PMA})_{2} \mathrm{PbI}_{4}$ by eliminating the ligands parts. The interaction energies between the ligands and the cages are listed for each compound. 


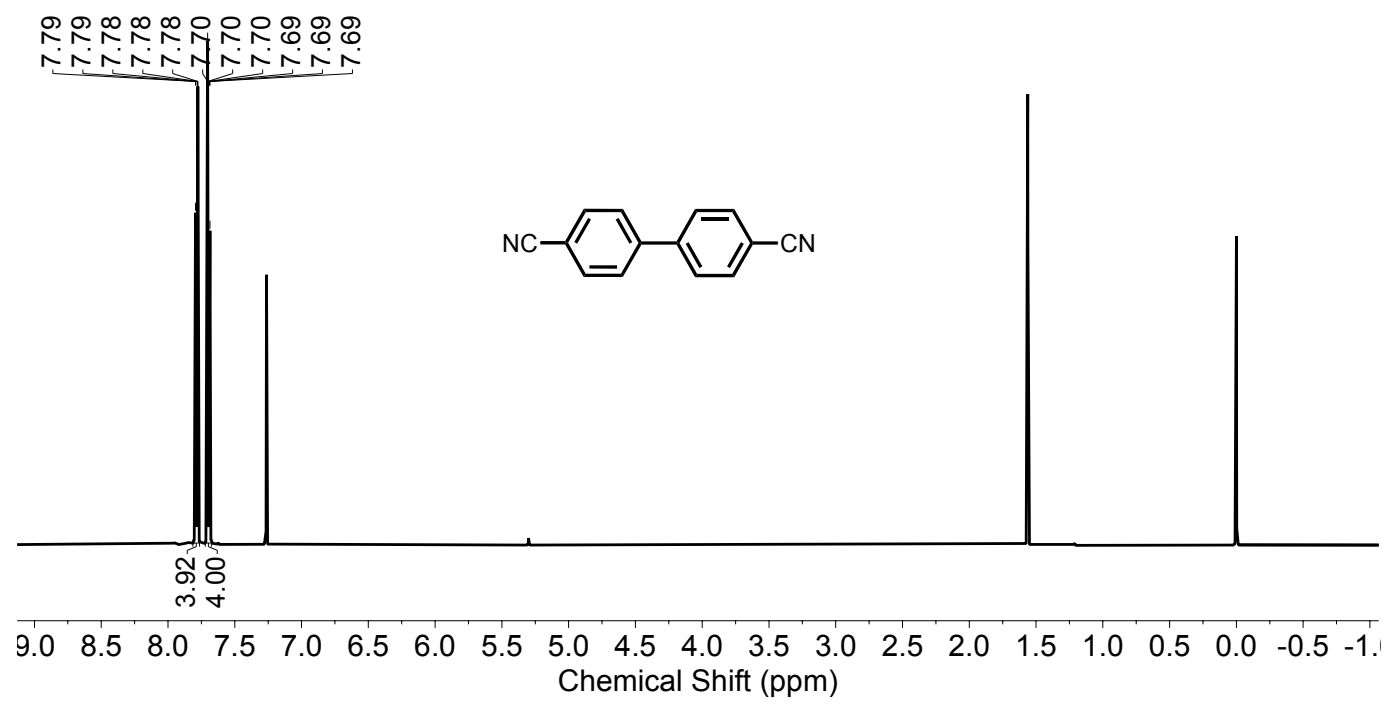

Figure S15. ${ }^{1} \mathrm{H} \mathrm{NMR}\left(\mathrm{CDCl}_{3}, 500 \mathrm{MHz}, 25^{\circ} \mathrm{C}\right)$ spectrum of PP2CN.
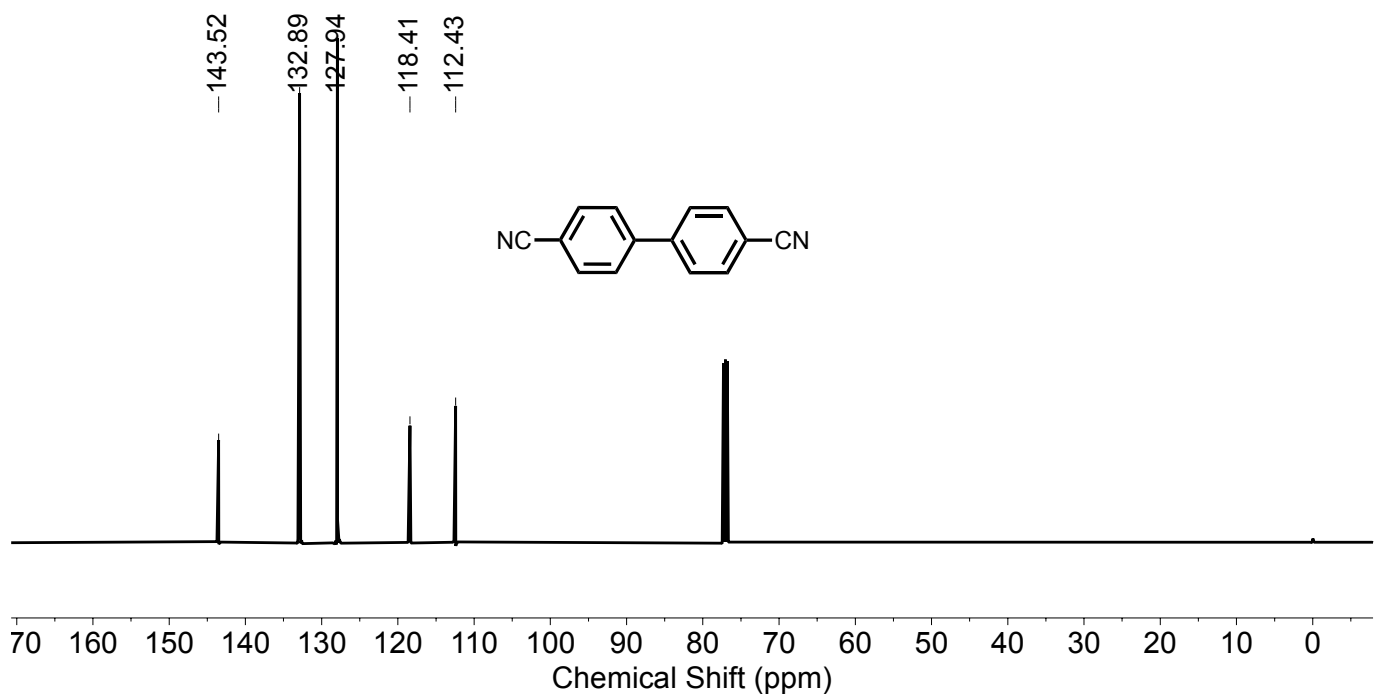

Figure S16. ${ }^{13} \mathrm{C} \mathrm{NMR}\left(\mathrm{CDCl}_{3}, 126 \mathrm{MHz}, 25^{\circ} \mathrm{C}\right)$ spectrum of PP2CN. 


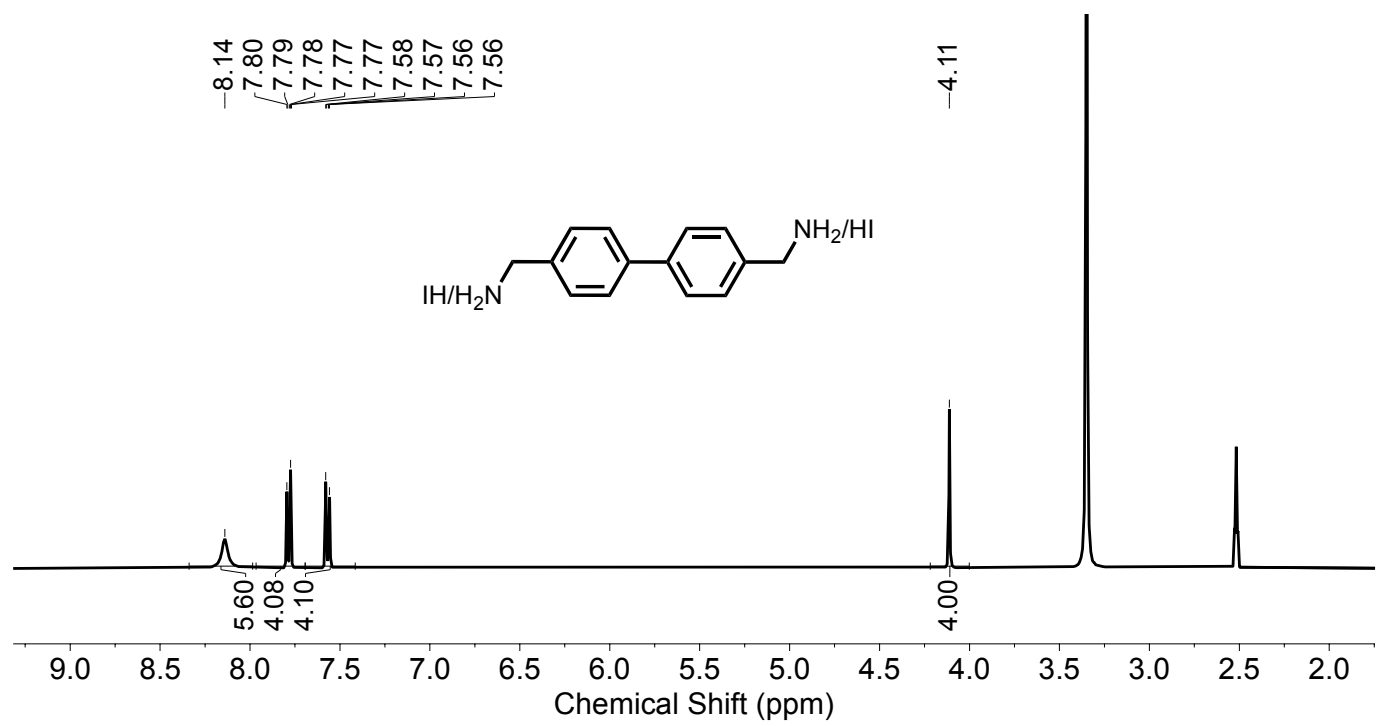

Figure S17. ${ }^{1} \mathrm{H}$ NMR (DMSO, $400 \mathrm{MHz}, 25^{\circ} \mathrm{C}$ ) spectrum of PP-2I.
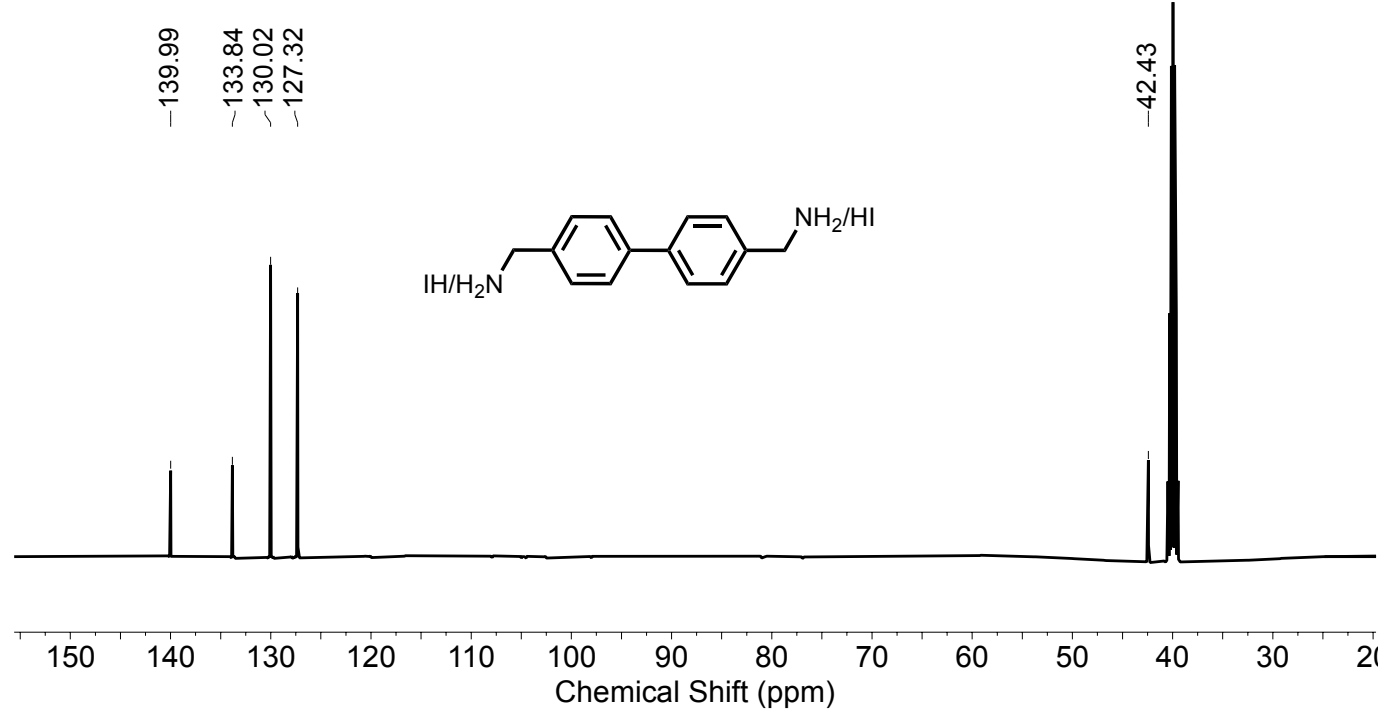

Figure S18. ${ }^{13} \mathrm{C}$ NMR (DMSO, $126 \mathrm{MHz}, 25{ }^{\circ} \mathrm{C}$ ) spectrum of PP-2I. 


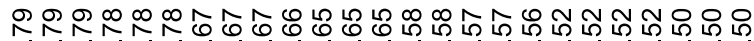

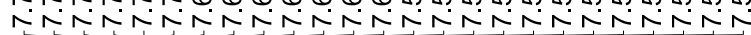

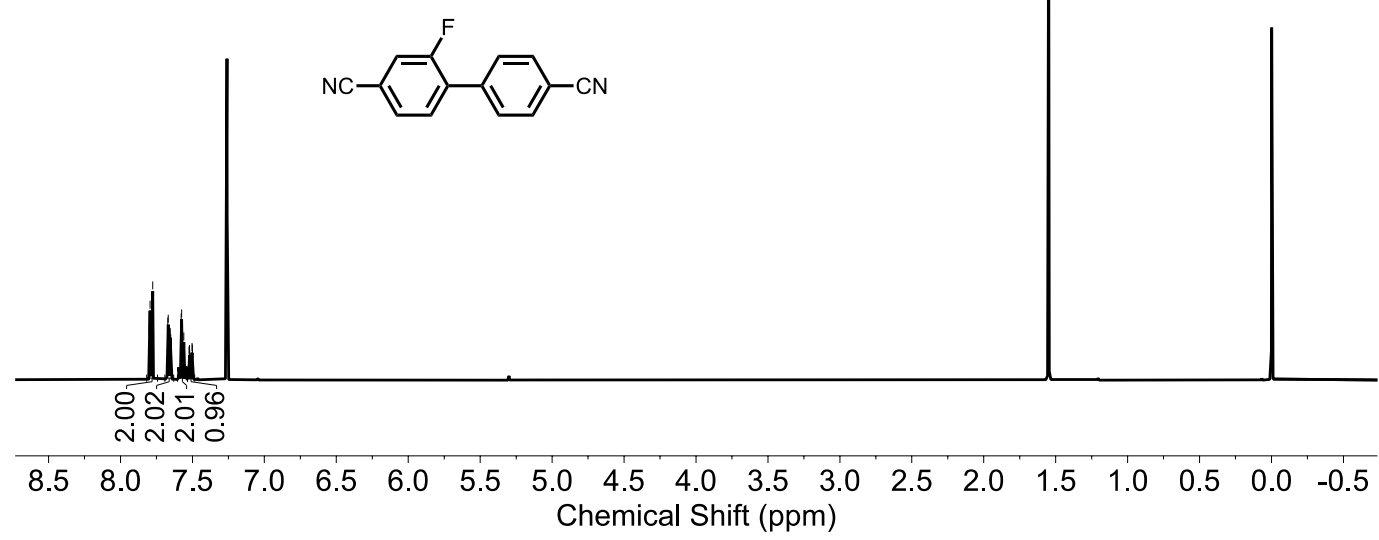

Figure S19. ${ }^{1} \mathrm{H}$ NMR $\left(\mathrm{CDCl}_{3}, 500 \mathrm{MHz}, 25^{\circ} \mathrm{C}\right)$ spectrum of FPP2CN.

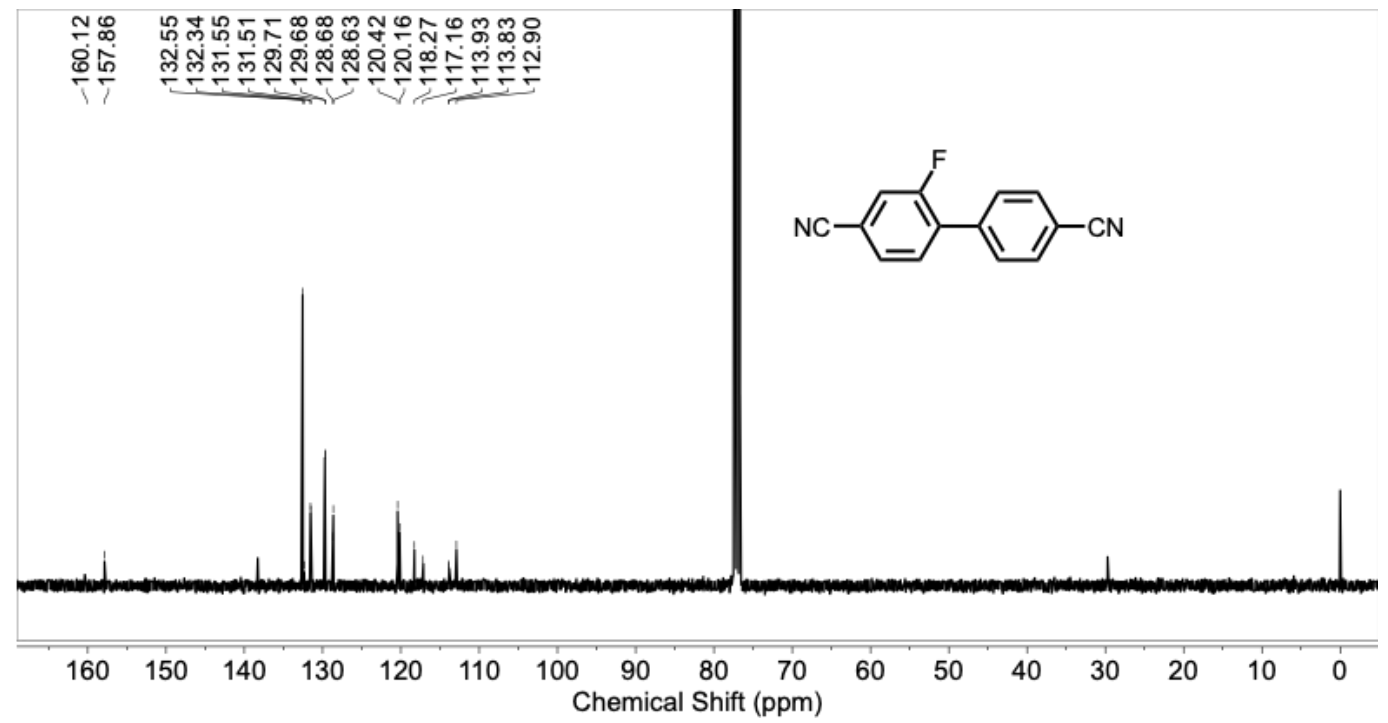

Figure S20. ${ }^{13} \mathrm{C}$ NMR $\left(\mathrm{CDCl}_{3}, 101 \mathrm{MHz}, 25^{\circ} \mathrm{C}\right)$ spectrum of FPP2CN. 

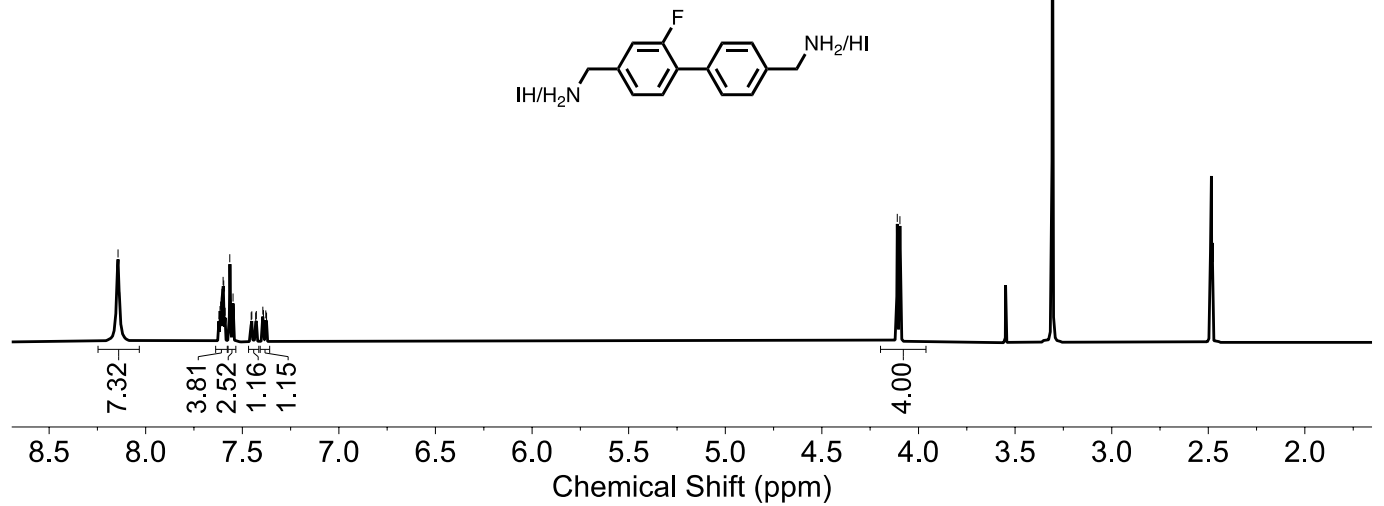

Figure S21. ${ }^{1} \mathrm{H}$ NMR (DMSO, $500 \mathrm{MHz}, 25^{\circ} \mathrm{C}$ ) spectrum of FPP-2I.
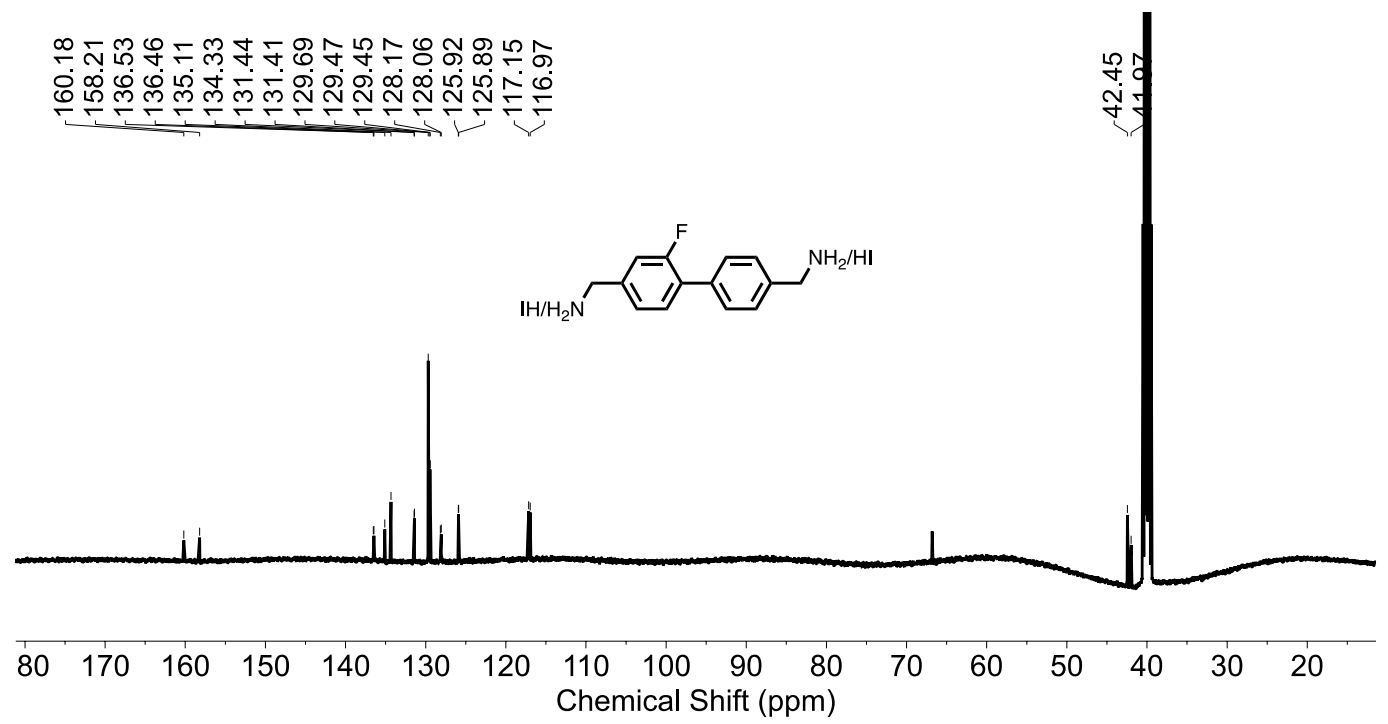

Figure S22. ${ }^{13} \mathrm{C} \mathrm{NMR}\left(\mathrm{CDCl}_{3}, 126 \mathrm{MHz}, 25{ }^{\circ} \mathrm{C}\right)$ spectrum of FPP-2I. 


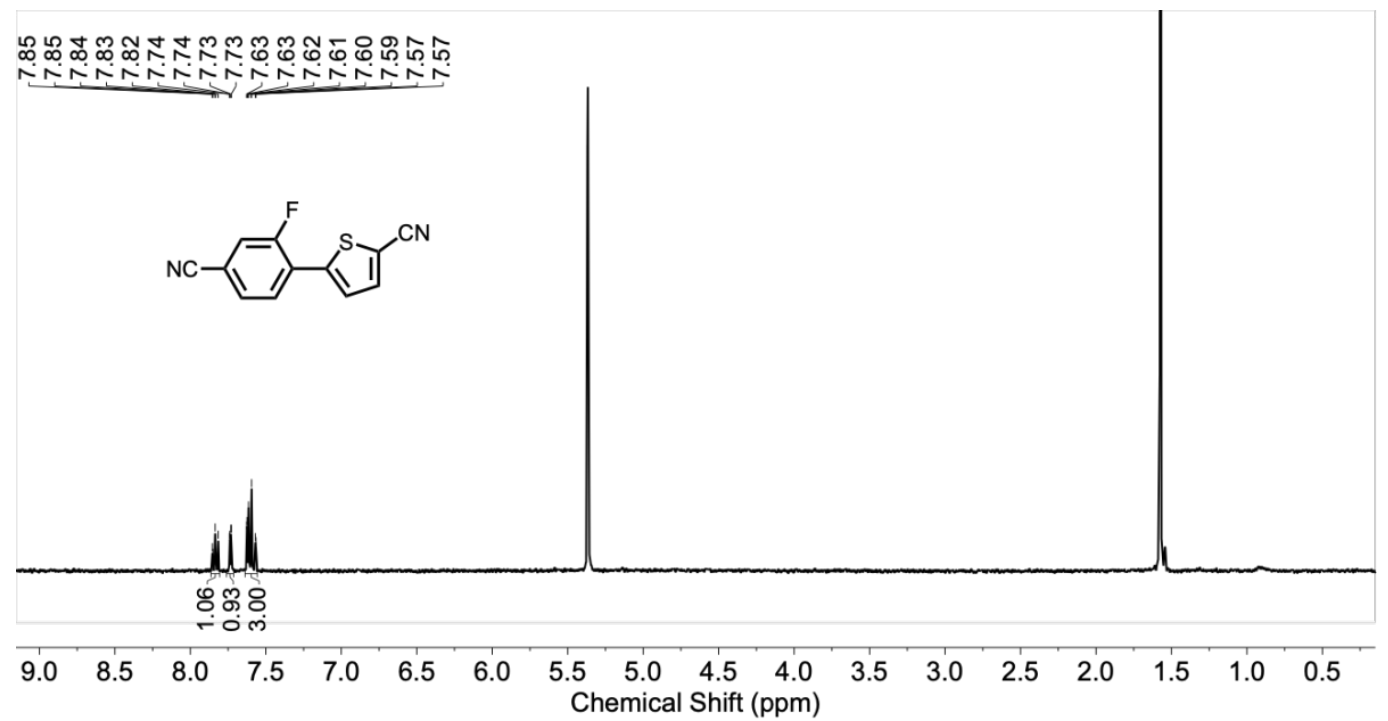

Figure S23. ${ }^{1} \mathrm{H}$ NMR $\left(\mathrm{CD}_{2} \mathrm{Cl}_{2}, 400 \mathrm{MHz}, 25^{\circ} \mathrm{C}\right)$ spectrum of FPT2CN.

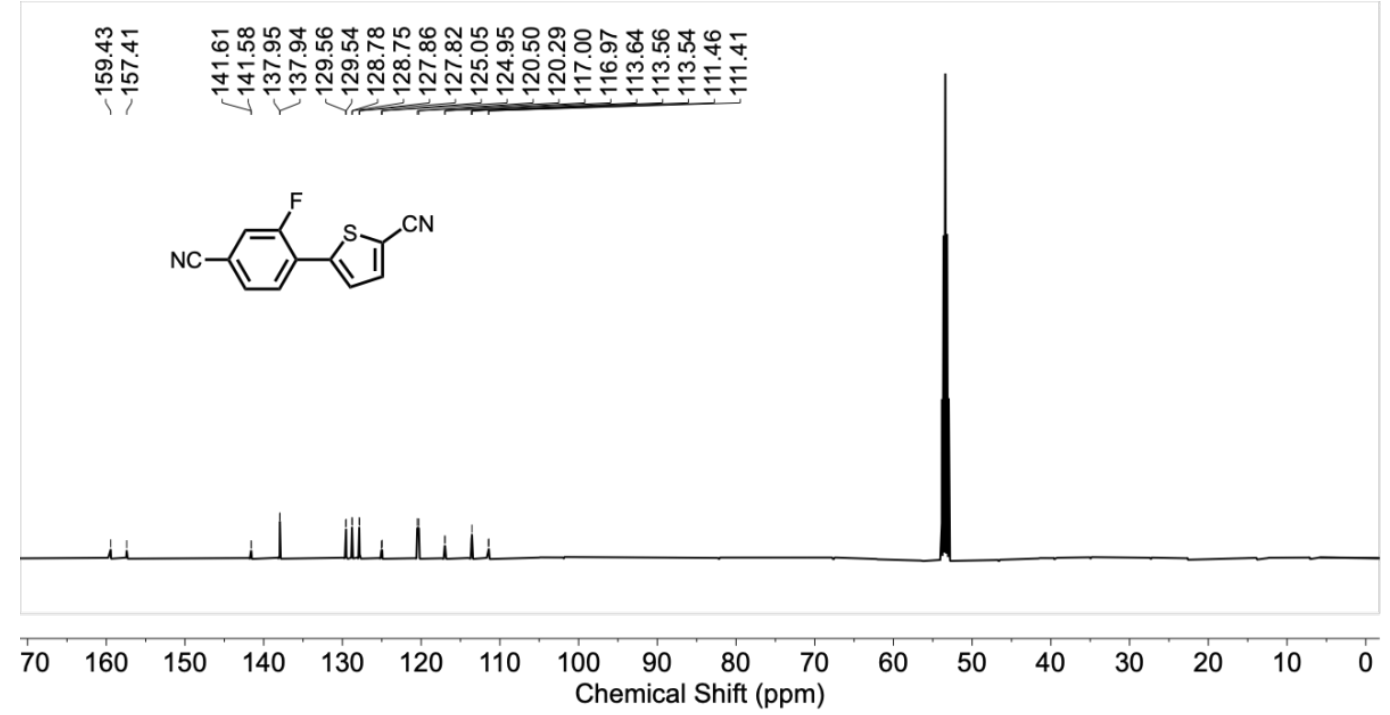

Figure S24. ${ }^{13} \mathrm{C}$ NMR $\left(\mathrm{CD}_{2} \mathrm{Cl}_{2}, 126 \mathrm{MHz}, 25^{\circ} \mathrm{C}\right)$ spectrum of FPT2CN. 


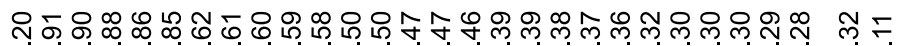

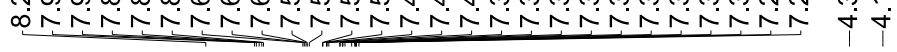

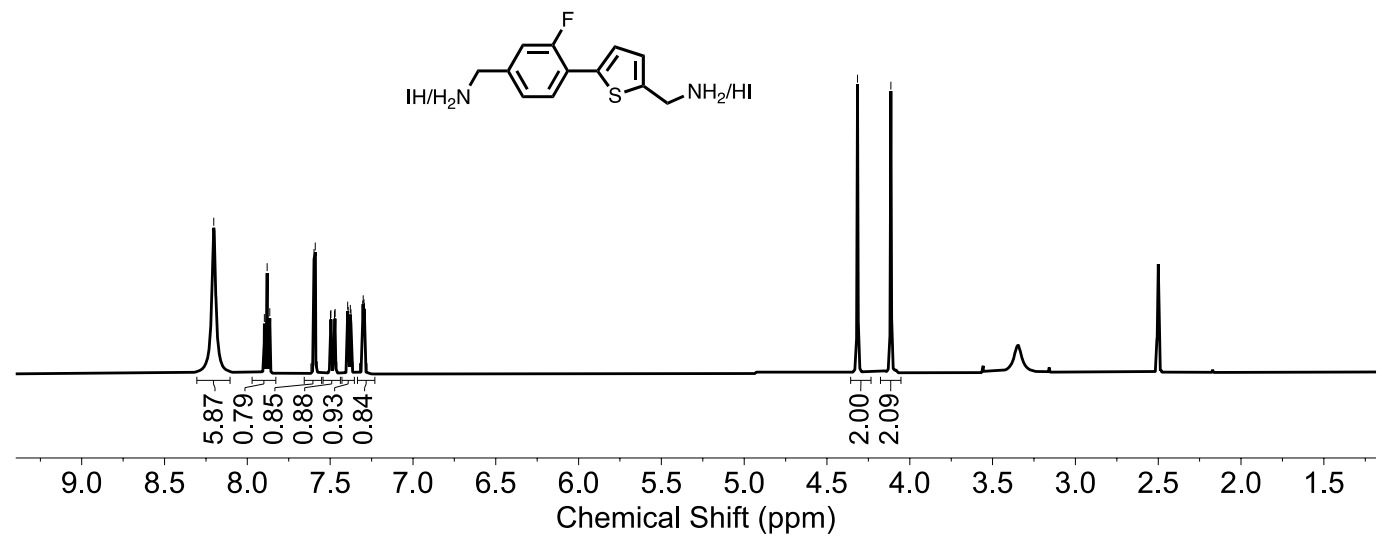

Figure S25. ${ }^{1} \mathrm{H}$ NMR(DMSO, $500 \mathrm{MHz}, 25^{\circ} \mathrm{C}$ ) spectrum of FPT-2I.

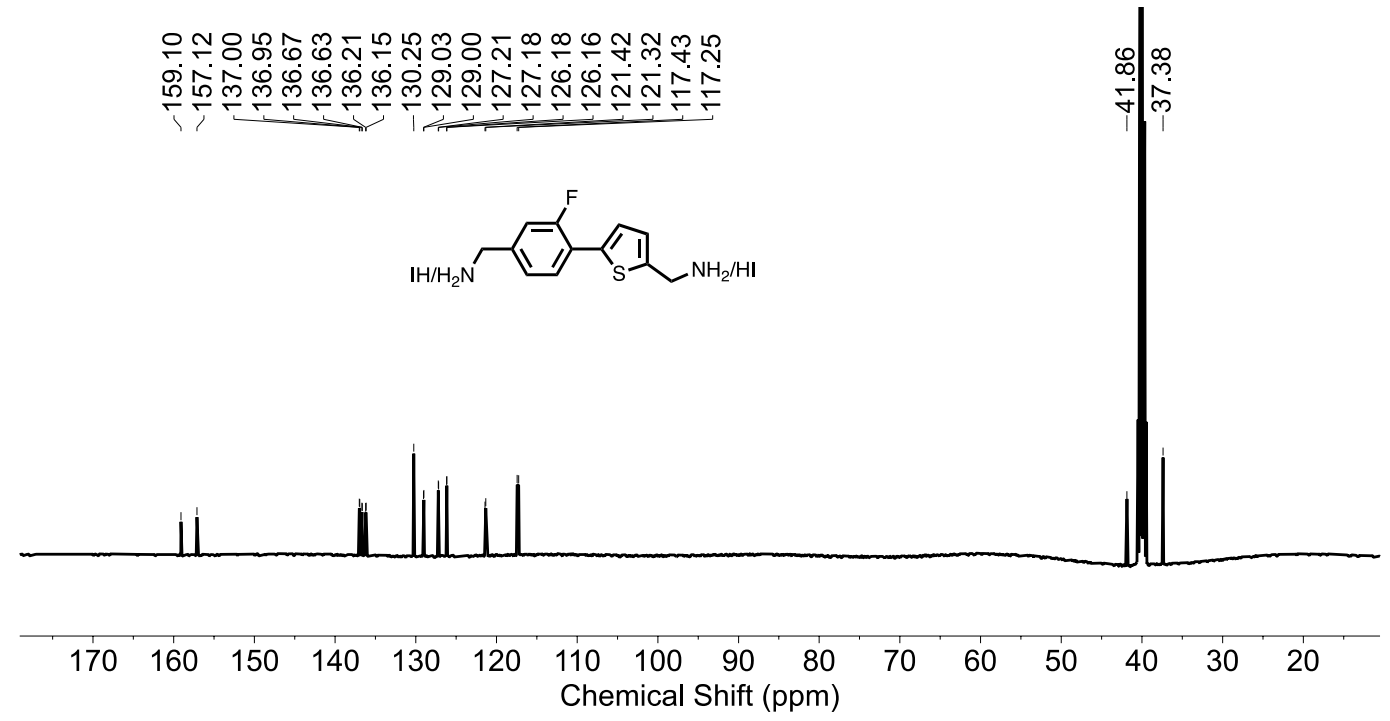

Figure S26. ${ }^{13} \mathrm{C}$ NMR (DMSO, $126 \mathrm{MHz}, 25^{\circ} \mathrm{C}$ ) spectrum of FPT-2I. 


\section{References}

(1) Blum, V.; Gehrke, R.; Hanke, F.; Havu, P.; Havu, V.; Ren, X.; Reuter, K.; Scheffler, M. Ab Initio Molecular Simulations with Numeric Atom-Centered Orbitals. Comput.Phys. Commun. 2009, 180, 2175-2196.

(2) Havu, V.; Blum, V.; Havu, P.; Scheffler, M. Efficient O (N) Integration for All-Electron Electronic Structure Calculation Using Numeric Basis Functions. J.Comput. Phys. 2009, $228,8367-8379$.

(3) Ren, X.; Rinke, P.; Blum, V.; Wieferink, J.; Tkatchenko, A.; Sanfilippo, A.; Reuter, K.;

Scheffler, M. Resolution-of-Identity Approach to Hartree-Fock, Hybrid Density Functionals, RPA, MP2 and GW with Numeric Atom-Centered Orbital Basis Functions. New J. Phys. 2012, 14, 053020.

(4) Perdew, J. P.; Burke, K.; Ernzerhof, M. Generalized Gradient Approximation Made Simple. Phys. Rev. Lett. 1996, 77, 3865-3868.

(5) Tkatchenko, A.; Scheffler, M. Accurate Molecular van Der Waals Interactions from Ground-State Electron Density and Free-Atom Reference Data. Phys. Rev. Lett. 2009, 102, 073005 .

(6) Heyd, J.; Scuseria, G. E.; Ernzerhof, M. Hybrid Functionals Based on a Screened Coulomb Potential. J. Chem. Phys. 2003, 118, 8207-8215.

(7) Huhn, W. P.; Blum, V. One-Hundred-Three Compound Band-Structure Benchmark of PostSelf-Consistent Spin-Orbit Coupling Treatments in Density Functional Theory. Phys. Rev. Mater. 2017, 1, 033803.

(8) Togo, A.; Tanaka, I. First Principles Phonon Calculations in Materials Science. Scr. Mater. 2015, 108, 1-5.

(9) Kamminga, M. E.; Fang, H. H.; Filip, M. R.; Giustino, F.; Baas, J.; Blake, G. R.; Loi, M. A.; Palstra, T. T. M. Confinement Effects in Low-Dimensional Lead Iodide Perovskite Hybrids. Chem. Mater. 2016, 28, 4554-4562. 
Table S1. Crystal data and structure refinement for $(\mathbf{F P P}) \mathbf{P b I}_{4}$.

\begin{tabular}{|c|c|}
\hline & $(\mathrm{FPP}) \mathrm{PbI}_{4}$ \\
\hline Empirical formula & $\mathrm{C} 14 \mathrm{H} 17 \mathrm{~F}$ I4 N2 Pb \\
\hline Formula weight & 947.09 \\
\hline Temperature & $150(2) \mathrm{K}$ \\
\hline Wavelength & $0.71073 \AA$ \\
\hline Crystal system & Orthorhombic \\
\hline Space group & Pcca \\
\hline Unit cell dimensions & $\begin{array}{l}\mathrm{a}=11.9481(7) \AA, \alpha=90^{\circ} \\
\mathrm{b}=14.2546(10) \AA, \beta=90^{\circ} \\
\mathrm{c}=12.7180(8) \AA, \gamma=90^{\circ}\end{array}$ \\
\hline Volume & $2166.1(2) \AA^{3}$ \\
\hline $\mathrm{Z}$ & 4 \\
\hline Density (calculated) & $2.904 \mathrm{Mg} / \mathrm{m}^{3}$ \\
\hline Absorption coefficient & $13.496 \mathrm{~mm}^{-1}$ \\
\hline$F(000)$ & 1672 \\
\hline Crystal size & $0.160 \times 0.160 \times 0.060 \mathrm{~mm}^{3}$ \\
\hline Theta range for data collection & 2.741 to $27.493^{\circ}$ \\
\hline Index ranges & $-13<=\mathrm{h}<=15,-18<=\mathrm{k}<=14,-16<=1<=12$ \\
\hline Reflections collected & 14466 \\
\hline Independent reflections & $2478[R($ int $)=0.0565]$ \\
\hline Completeness to theta $=25.242^{\circ}$ & $99.4 \%$ \\
\hline Absorption correction & Semi-empirical from equivalents \\
\hline Max. and min. transmission & 0.7456 and 0.3703 \\
\hline Refinement method & Full-matrix least-squares on $\mathrm{F}^{2}$ \\
\hline Data / restraints / parameters & $2478 / 0 / 107$ \\
\hline Goodness-of-fit on $\mathrm{F}^{2}$ & 1.079 \\
\hline Final $R$ indices $[\mathrm{I}>2 \operatorname{sigma}(\mathrm{I})]$ & $\mathrm{R} 1=0.0316, \mathrm{wR} 2=0.0883$ \\
\hline $\mathrm{R}$ indices (all data) & $\mathrm{R} 1=0.0390, \mathrm{wR} 2=0.0923$ \\
\hline Extinction coefficient & $\mathrm{n} / \mathrm{a}$ \\
\hline Largest diff. peak and hole & 1.753 and -1.962 e. $\AA^{-3}$ \\
\hline
\end{tabular}


Table S2. Crystal data and structure refinement for FPP-2I.

\begin{tabular}{|c|c|}
\hline & FPP-2I \\
\hline Empirical formula & $\mathrm{C} 14 \mathrm{H} 17 \mathrm{~F}$ I2 N2 \\
\hline Formula weight & 486.09 \\
\hline Temperature & $150(2) \mathrm{K}$ \\
\hline Wavelength & $0.71073 \AA$ \\
\hline Crystal system & Triclinic \\
\hline Space group & P-1 \\
\hline Unit cell dimensions & $\begin{array}{l}\mathrm{a}=4.5614(4) \AA, \alpha=81.038(3)^{\circ} \\
\mathrm{b}=6.3915(6) \AA, \beta=89.216(3)^{\circ} \\
\mathrm{c}=13.8661(12) \AA, \gamma=83.622(3)^{\circ}\end{array}$ \\
\hline Volume & $396.85(6) \AA^{3}$ \\
\hline $\mathrm{Z}$ & 1 \\
\hline Density (calculated) & $2.034 \mathrm{Mg} / \mathrm{m}^{3}$ \\
\hline Absorption coefficient & $3.962 \mathrm{~mm}^{-1}$ \\
\hline $\mathrm{F}(000)$ & 230 \\
\hline Crystal size & $0.110 \times 0.080 \times 0.020 \mathrm{~mm}^{3}$ \\
\hline Theta range for data collection & 2.974 to $27.577^{\circ}$ \\
\hline Index ranges & $-5<=\mathrm{h}<=5,-8<=\mathrm{k}<=6,-17<=1<=17$ \\
\hline Reflections collected & 6077 \\
\hline Independent reflections & $1815[\mathrm{R}(\mathrm{int})=0.0350]$ \\
\hline Completeness to theta $=25.242^{\circ}$ & $99.6 \%$ \\
\hline Absorption correction & Semi-empirical from equivalents \\
\hline Max. and min. transmission & 0.7456 and 0.6608 \\
\hline Refinement method & Full-matrix least-squares on $\mathrm{F}^{2}$ \\
\hline Data / restraints / parameters & $1815 / 103 / 100$ \\
\hline Goodness-of-fit on $\mathrm{F}^{2}$ & 1.073 \\
\hline Final $R$ indices $[\mathrm{I}>2 \operatorname{sigma}(\mathrm{I})]$ & $\mathrm{R} 1=0.0339, \mathrm{wR} 2=0.0826$ \\
\hline $\mathrm{R}$ indices (all data) & $\mathrm{R} 1=0.0426, \mathrm{wR} 2=0.0851$ \\
\hline Extinction coefficient & $\mathrm{n} / \mathrm{a}$ \\
\hline Largest diff. peak and hole & 1.415 and -1.454 e..$\AA^{-3}$ \\
\hline
\end{tabular}


Table S3. Crystal data and structure refinement for (PP)Pb $\mathbf{I}_{2} \mathbf{I}_{6}$.

\begin{tabular}{|c|c|}
\hline & $(\mathbf{P P}) \mathrm{Pb}_{2} \mathbf{I}_{6}$ \\
\hline Empirical formula & $\mathrm{C} 14 \mathrm{H} 18 \mathrm{I} 6 \mathrm{~N} 2 \mathrm{~Pb} 2$ \\
\hline Formula weight & 1390.08 \\
\hline Temperature & $295(2) \mathrm{K}$ \\
\hline Wavelength & $0.71073 \AA$ \\
\hline Crystal system & Triclinic \\
\hline Space group & $\mathrm{P}-1$ \\
\hline Unit cell dimensions & $\begin{array}{l}\mathrm{a}=4.7204(3) \AA, \alpha=107.420(2)^{\circ} \\
\mathrm{b}=11.7340(8) \AA, \beta=95.478(2)^{\mathrm{o}} \\
\mathrm{c}=12.3863(8) \AA, \gamma=90.162(2)^{\mathrm{o}}\end{array}$ \\
\hline Volume & $651.25(7) \AA^{3}$ \\
\hline $\mathrm{Z}$ & 1 \\
\hline Density (calculated) & $3.544 \mathrm{Mg} / \mathrm{m}^{3}$ \\
\hline Absorption coefficient & $20.022 \mathrm{~mm}^{-1}$ \\
\hline $\mathrm{F}(000)$ & 598 \\
\hline Crystal size & $0.180 \times 0.040 \times 0.040 \mathrm{~mm}^{3}$ \\
\hline Theta range for data collection & 1.820 to $27.503^{\circ}$ \\
\hline Index ranges & $-6<=\mathrm{h}<=6,-15<=\mathrm{k}<=15,-16<=1<=16$ \\
\hline Reflections collected & 20807 \\
\hline Independent reflections & $2975[\mathrm{R}($ int $)=0.0416]$ \\
\hline Completeness to theta $=25.242^{\circ}$ & $99.5 \%$ \\
\hline Absorption correction & Semi-empirical from equivalents \\
\hline Max. and min. transmission & 0.7456 and 0.3609 \\
\hline Refinement method & Full-matrix least-squares on $\mathrm{F}^{2}$ \\
\hline Data / restraints / parameters & $2975 / 0 / 110$ \\
\hline Goodness-of-fit on $\mathrm{F}^{2}$ & 1.058 \\
\hline Final $R$ indices $[\mathrm{I}>2 \operatorname{sigma}(\mathrm{I})]$ & $\mathrm{R} 1=0.0243, \mathrm{wR} 2=0.0572$ \\
\hline $\mathrm{R}$ indices (all data) & $\mathrm{R} 1=0.0316, \mathrm{wR} 2=0.0595$ \\
\hline Extinction coefficient & $0.0069(3)$ \\
\hline Largest diff. peak and hole & 1.167 and $-1.066 \mathrm{e} . \AA^{-3}$ \\
\hline
\end{tabular}

